\title{
Fish Processing Industry Residues: A Review of Valuable Products Extraction and Characterization Methods
}

\author{
Pedro Ideia $^{1} \cdot$ Joana Pinto ${ }^{1} \cdot$ Rui Ferreira $^{1} \cdot$ Leandro Figueiredo $^{1} \cdot$ Vítor Spínola $^{2}\left(\mathbb{D} \cdot\right.$ Paula C. Castilho $^{1}$
}

Received: 11 February 2019 / Accepted: 25 June 2019

(c) Springer Nature B.V. 2019

\begin{abstract}
Fish processing industry has experienced significant growth, playing an important role in the world economy. The increased exploration of marine resources contributes to the generation of considerable amounts of biowaste, which ends up as discards. In the face of the resultant disposal and environmental problems, many efforts have been made to deal with the fishery waste in more efficient ways. Nowadays, these by-products are regarded as important sources of high added value compounds, such as hydroxyapatite, collagen, gelatin, lipids, enzymes, hydrolysates and bioactive peptides, with great potential for human health applications. The present paper aims to review the current methods of extraction and characterization of added value products from fish by-products, as well as their actual and potential applications.
\end{abstract}

\section{Graphic Abstract}

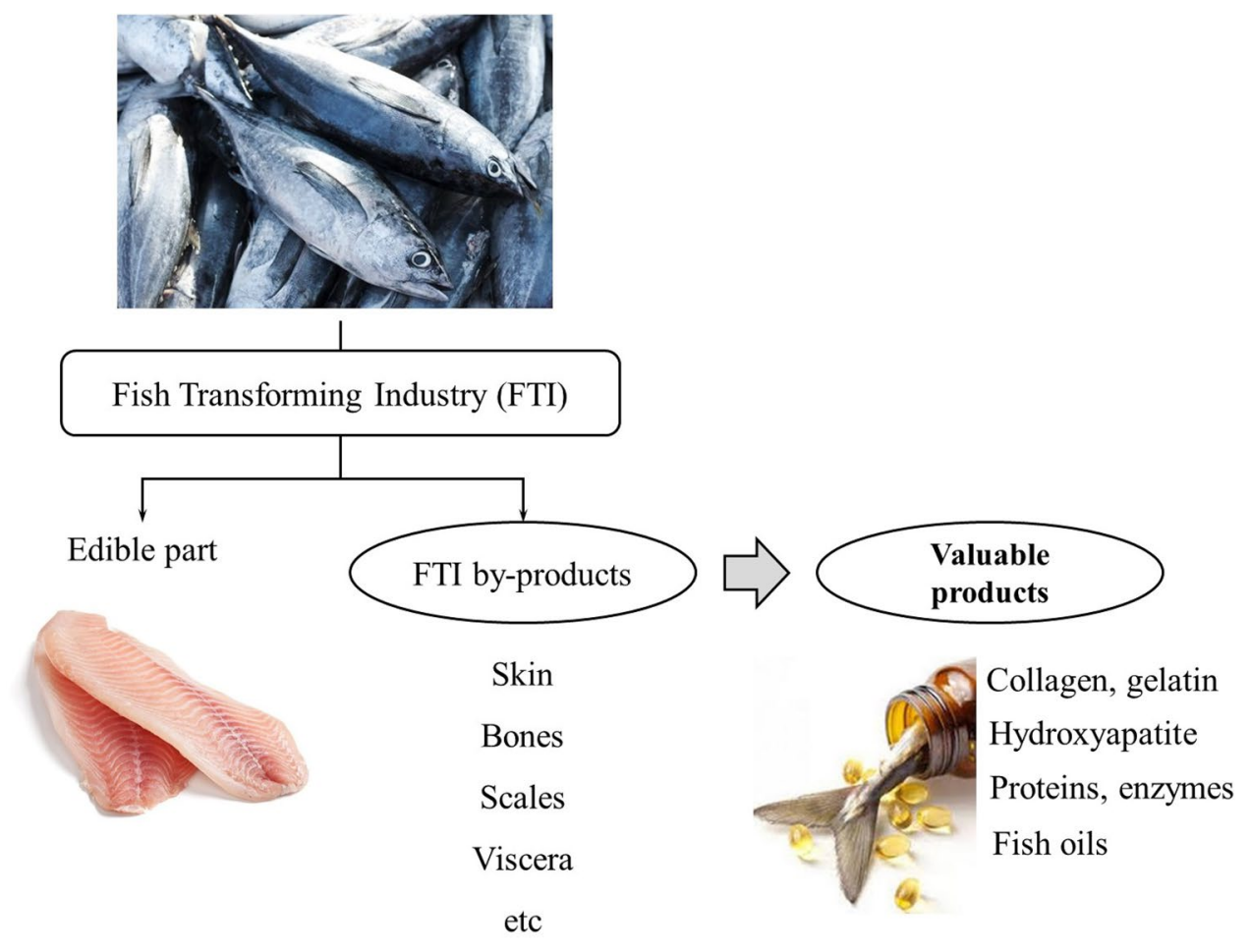

Keywords Fish processing industry $\cdot$ Marine resources $\cdot$ Waste $\cdot$ By-products $\cdot$ High added value compounds

Paula C. Castilho

pcastilho@staff.uma.pt

Extended author information available on the last page of the article 


\section{Statement of Novelty}

The increased exploration of marine resources contributes to the generation of considerable amounts of biowaste. Marine processing by-products have brought more value out of what is until recently regarded as biowaste. These residues, commonly discarded, have been considered for their potential to generate high added value compounds, such as hydroxyapatite, collagen, enzymes, proteins and fish oils, etc. Previous studies have shown the efforts made so far to maximize these marine sources by exploring different variables (e.g. fish species, extraction procedures, etc.). Our review intends to provide an overview of the research being carried out for the extraction of high added value compounds from fish by-products. In this review, we covered the most important methods of extraction and characterization available for these compounds. The updated information and critical analysis on this issue will largely benefit the research dedicated to this topic.

\section{Introduction}

According to the Food and Agriculture Organization (FAO), fish production is continuously growing at an average rate of 3.2\% each year, reaching 158 million tons of fish captured in 2012 [1].

Fish processing industry (FPI) is responsible for the production of significant amounts of seafood and marine products. Only $40 \%$ of the catch is used for human consumption while more than $60 \%$ is discarded. As a result, considerable amounts of waste are generated [2,3], causing severe environmental problems that have been addressed to the fact that these discards have no direct application. The dual problem arising from fish processing industries which comprise environmental issues and the less profitable applications for by-products and waste have emphasised the need to obtain valorisation from fish processing waste and, at the same time, contribute to a more sustainable fish industry.

Aware of these serious problems, fish industries have made some efforts to deal efficiently with fish waste, including the application as animal feed, plant fertilizers, fish oil and fish meals [4]. However, in the context of biowaste valorization, these products are not economically attractive to fish industries [3, 5].

The paradigm is changing and the processing of byproducts can transform a product with low value into a product that is able to cover all the costs of processing and disposal, with consequent higher added value and reduced environmental damage [6].

These fish by-products comprise carcass, head, skin, scales, bones and viscera. In this sense, researchers have reported the finding of high value products that could be extracted from fish by-products, including proteins (proteolytic enzymes, protein hydrolysates, bioactive peptides, collagen and gelatin), fish oils and hydroxyapatite [7-11]. In fact, the extraction of these compounds seems to be economically promising for their recognised positive impact on human health. Regarded as high added value compounds (HAVC) these products show great potential for a variety of applications, from human foodstuffs and food ingredients to pharmaceuticals, medical and cosmetic products [3, 12-14]. Therefore, the search for new methodologies for extraction and purification of high-value products from fish waste may represent an excellent opportunity for the fish processing industries to bring more value to what is so far regarded as waste.

This review intends to analyse and discuss the methods available for the extraction of selected high added-value compounds from fish processing waste as well as their characterization. Also, it explores the potential applications of extracted components. Table 1 summarizes the information covered throughout the review, namely in terms of extraction and characterization of the different valuable products.

\section{Proteolytic Enzymes}

The fish internal organs (or viscera) constitute about $5 \%$ of fish weight and are one of the most important by-products from the FPI. Along the fish gastrointestinal system, different types of enzymes are secreted, making viscera a rich natural and cheap source of enzymes [12]. Different factors, such as life cycle, age, distribution, feeding and season, can lead to natural variations in the amount of proteolytic enzymes produced by many fish species [15]. An efficient and economic process for isolation of the enzymes from viscera would be preferable for the fish industry [16]. Enzymebased processes have an important role in the fish industry, including fish and sea food processing (deskinning, descaling, peeling), production and/or recovery of by-products (fish protein hydrolysates, fish curing and fermentation, collagen and pigments extraction, etc.) and enhancement of shelf-life and product quality [17]. Applications in the other areas of the food and textile industries, clinical and diagnosis are also documented [4].

Among naturally available enzymes from marine sources, proteases (including pepsin, trypsin and chymotrypsin, collagenase, etc.) constitute the most important group with commercial expression [4]. This group refer to all enzymes which catalyse the hydrolysis of proteins into polypeptides [18]. Pepsin and trypsin are presented in this review as two representative enzymes of acidic and alkaline proteases, respectively. 
Table 1 Summary of the methods for extraction and characterization of different valuable products from the fish processing industry (FPI) byproducts

\begin{tabular}{|c|c|c|c|}
\hline Source & Extraction and purification & Characterization & References \\
\hline \multicolumn{4}{|l|}{ Pepsin } \\
\hline Viscera (stomach) & $\begin{array}{l}\text { Extraction: } \\
\text { Preparation of crude extract with } \\
\text { buffer solution } \\
\text { Purification: } \\
\text { Ammonia sulfate fractionation } \\
\quad \text { (ASF) } \\
\text { Ion-exchange chromatography (IEC) } \\
\text { Gel filtration chromatography (GFC) } \\
\text { Aqueous two phase system (ATPS) }\end{array}$ & $\begin{array}{l}\text { Protein concentration } \\
\text { Determination of enzyme activity } \\
\text { Purity, homogeneity and molecular } \\
\text { mass } \\
\text { Structure determination (SDS- } \\
\text { PAGE) } \\
\text { Isoelectric focusing } \\
\text { Enzyme kinetic studies } \\
\text { Effect of inhibitors and activators }\end{array}$ & {$[4,16,19-28,30-41]$} \\
\hline \multicolumn{4}{|l|}{ Trypsin } \\
\hline $\begin{array}{l}\text { Viscera (pyloric caeca, intestine } \\
\text { and spleen) }\end{array}$ & $\begin{array}{l}\text { Extraction: } \\
\text { Extraction with buffers (i.e. Tris- } \\
\text { HCl) } \\
\text { Purification: } \\
\text { Ammonia sulfate fractionation } \\
\text { (ASF) } \\
\text { Dialysis } \\
\text { Gel filtration chromatography (GFC) }\end{array}$ & & \\
\hline \multicolumn{4}{|l|}{ Proteins and protein hydrolysates } \\
\hline Fish by-products, in general & $\begin{array}{l}\text { Enzymatic hydrolysis } \\
\text { Autolysis } \\
\text { Thermal hydrolysis } \\
\text { Bacteria fermentation }\end{array}$ & $\begin{array}{l}\text { Protein concentration } \\
\text { Fourier transform infrared spectros- } \\
\text { copy (FTIR) } \\
\text { X-Ray diffraction (XRD }\end{array}$ & {$[2,45-51,53,54,58-64]$} \\
\hline $\begin{array}{l}\text { Bioactive pepties } \\
\text { Fish by-products, in general }\end{array}$ & $\begin{array}{l}\text { Isolation from fish protein fractions: } \\
\text { Nanofiltration } \\
\text { Ion-exchange membranes } \\
\text { Reverse-phase HPLC }\end{array}$ & $\begin{array}{l}\text { Molecular weight (SDS-PAGE) } \\
\text { Evaluation of functional properties } \\
\text { (solubility, water and oil absorp- } \\
\text { tion) and suface active properties } \\
\text { (emulsifying and foaming proper- } \\
\text { ties) } \\
\text { Bioactive properties (i.e. antioxidant } \\
\text { and antibacterial activity) }\end{array}$ & \\
\hline \multicolumn{4}{|l|}{ Collagen } \\
\hline Mainly skin and scales & $\begin{array}{l}\text { Pretreatment: } \\
\text { Alkaline hydrolysis, demineraliza- } \\
\text { tion and degreasing } \\
\text { Extraction: } \\
\text { Acid treatment (ASC, acid-soluble } \\
\text { collagen) } \\
\text { Extraction with pepsin (PSC, pepsin- } \\
\text { soluble collagen) } \\
\text { Isolation: } \\
\text { Salting-out and dialysis }\end{array}$ & $\begin{array}{l}\text { Fourier transform infrared spectros- } \\
\text { copy (FTIR) } \\
\text { X-Ray diffraction (XRD) } \\
\text { Circular dichroism (CD) } \\
\text { Denaturation temperature (DSC, dif- } \\
\text { ferential scanning calorimetry) } \\
\text { Viscosity measurement } \\
\text { Molecular weight (SDS-PAGE) } \\
\text { Morphology (SEM) } \\
\text { UV-Visible spectrometry }\end{array}$ & $\begin{array}{l}{[6,73,74,79,86-89} \\
\quad 91-96,100,106-108]\end{array}$ \\
\hline Gelatin & & Effect of $\mathrm{pH}$ and $\mathrm{NaCl}$ on solubility & \\
\hline Mainly skin and scales & $\begin{array}{l}\text { Preparation by partial denaturation } \\
\text { of collagen: } \\
\text { Acid conditions (type A gelatin) } \\
\text { Alkaline conditions (type B gelatin) } \\
\text { Extraction from fish residues: } \\
\text { Non-collageneous proteins and } \\
\text { pigment removal, pretreatment } \\
\text { (chamical or enzymatic) and } \\
\text { thermolysis }\end{array}$ & Determination of isoelectric point & \\
\hline
\end{tabular}


Table 1 (continued)

\begin{tabular}{|c|c|c|c|}
\hline Source & Extraction and purification & Characterization & References \\
\hline \multicolumn{4}{|l|}{ Hydroxyapatite } \\
\hline Scales and bones & $\begin{array}{l}\text { Thermal calcination } \\
\text { Alkaline hydrolysis } \\
\text { Enzymatic hydrolysis } \\
\text { Ionic liquid pretreatment }\end{array}$ & $\begin{array}{l}\text { Thermal gravimetric analysis (TGA) } \\
\text { Fourier transform infrared spectros- } \\
\text { copy (FTIR) } \\
\text { X-Ray diffraction (XRD) } \\
\text { Chemical analysis } \\
\text { Morphology and particle size (SEM } \\
\text { and TEM) } \\
\text { In vitro cytotoxicity and proliferation } \\
\text { studies }\end{array}$ & {$[10,110,111,115-125]$} \\
\hline \multicolumn{4}{|l|}{ Fish oils } \\
\hline $\begin{array}{l}\text { Muscles and perivisceral organs } \\
\text { (liver and intestine) }\end{array}$ & $\begin{array}{l}\text { Organic solvents } \\
\text { Soxhlet extraction } \\
\text { Supercritical fluid extraction }\end{array}$ & $\begin{array}{l}\text { Thin layer chromatography (TLC) } \\
\text { Quantitative and qualitative charac- } \\
\text { terization (GC-FID and GC.MS) } \\
\text { Fourier transform infrared spectros- } \\
\text { copy (FTIR) } \\
\text { Nuclear magnetic resonance (NMR) }\end{array}$ & {$[4,126,127,129-142,146]$} \\
\hline
\end{tabular}

Enzymes, such as pepsin and trypsin are extracted from viscera, hydroxyapatite from bones and scales and collagen and gelatin mainly from skin and scales. Fish oils are isolated from muscles and perivisceral organs, such as liver and intestine, and proteins can be obtained from fish byproducts in general

\section{Extraction and Purification}

The first step of the extraction of enzymes from fish viscera involves the preparation of a crude extract with an appropriate buffer. Temperature, composition and $\mathrm{pH}$ of extraction buffers should be controlled in order to allow stabilization of the enzymes during the process. The most commonly used buffers are the sodium phosphate buffer and Tris- $\mathrm{HCl}$ buffer, containing $\mathrm{CaCl}_{2}$ and/or $\mathrm{NaCl}$. The recovery of enzymes depends on several factors, such as the amount and quality of raw materials and methodology used for extraction [4].

Purification of extracted enzyme can be achieved by different procedures, such as ammonia sulfate fractionation (ASF), ion-exchange chromatography (IEC) and gel filtration chromatography (GFC) [16]. Figure 1 summarizes the procedure for extraction and purification of proteolytic enzymes from fish viscera. Ammonium sulfate precipitation is widely used because is a simple, fast and low cost procedure when compared with other protocols [19]. The raw extract is then dialyzed, centrifuged and the precipitate is discarded. Some authors apply a heat treatment step (incubation at $45^{\circ} \mathrm{C}$ ) before or after ASF [19-22]. Although the heat treatment does not improve the purification performance, its inclusion has proven to improve the performance in the subsequent stages since it promotes the hydrolysis of the thermostable contaminating proteins [20,21]. Higher temperatures are not recommended, since enzymes most likely undergo denaturation and loss of their activity [23].

Some authors apply GFC to the crude enzyme extracts, using different types of stationary phases (e.g. Sephadex, DEAE-Sephacel, Sephacryl, Sepharose, etc.) [21, 23-25].
In addition to conventional methods of purification, aqueous two-phase system (ATPS) is also used, which is achieved by adding a salt aqueous solution to a polymer solution (commonly polyethylene glycol), resulting in a mixture of two immiscible solutions. Due to hydrophobic groups on their surface, proteins tend to migrate to the polymer phase [26-28]. Despite its advantages in terms of simplicity and duration, the purification factor, obtained by ATPS is typically lower than for conventional methods. Also, an additional precipitation step to separate the proteins from the polymeric phase is needed before further analysis/ characterization.

In order to obtain the enzymatic extract in its purest state, it is advisable to use more than one purification method sequentially (e.g. ASF followed by IEC or GFC) to avoid interferences from matrix (when using spectrophotometric analysis) and to improve the specific activity. However, when the goal is to use the extracted enzymes in other processes, such as fish waste processing, this exhaustive purification methods do not reveal mandatory [29].

\section{Characterization of Proteolytic Enzymes}

Colorimetric assays are commonly used to evaluate the enzymes activity, using specific substrates. Enzyme activity of pepsin is frequently performed using hemoglobin [30-35].

Different substrates for determination of trypsin activity are described in literature. N $\alpha$-benzoyl-DL-arginine- $p$ nitroanilide (BAPNA), a specific trypsin substrate, is the most common used [19, 20, 22, 23, 36]. However, when 


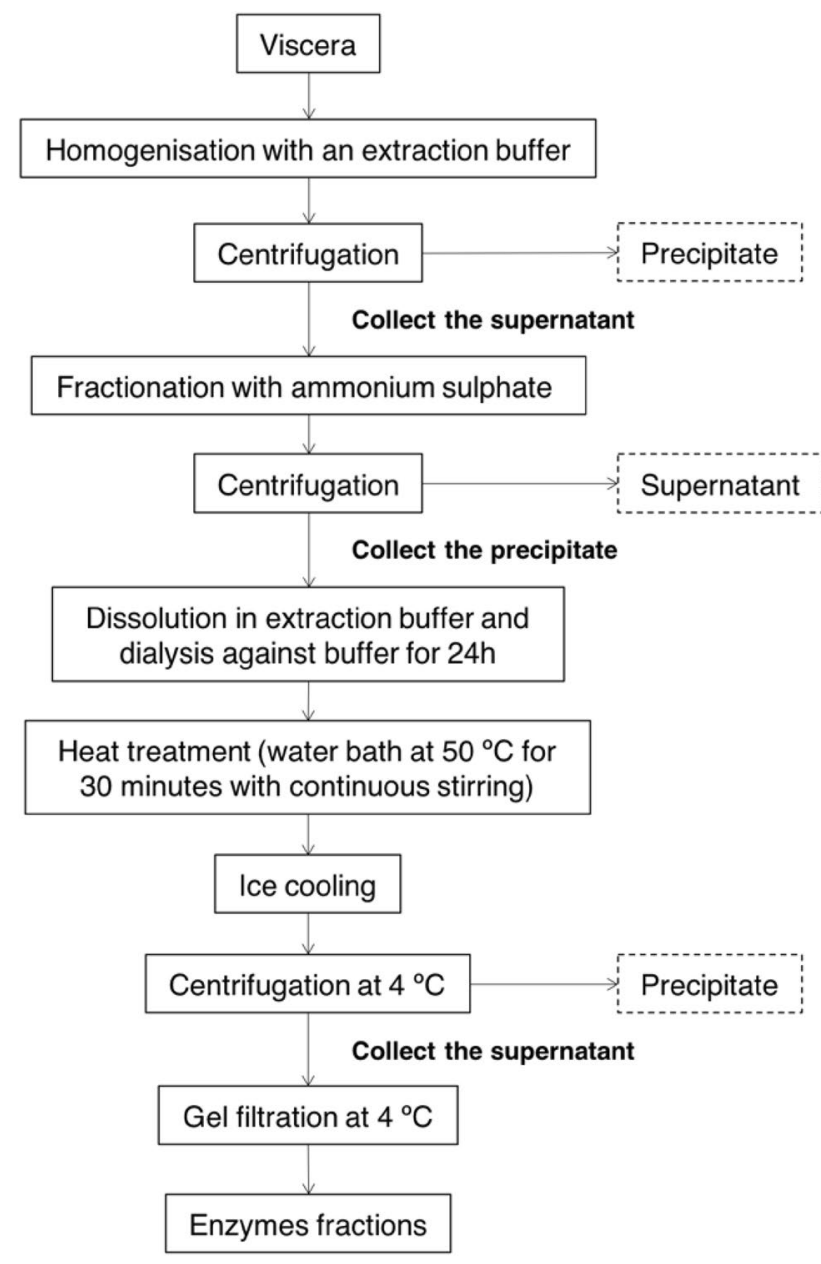

Fig. 1 Flowchart for the extraction of proteolytic enzymes (pepsin and trypsin) from fish viscera. Adapted from Shahidi and Janak Kamil [18]

BAPNA was used, the catalytic activity of the enzyme was not significantly reduced with the increase in $\mathrm{pH}$ value [22]. Casein [21, 25], and N $\alpha$ - $p$-Tosyl-L-arginine methyl ester hydrochloride (TAME) [24, 37, 38] are used in less extent. A fluorimetric assay to measure trypsin activity was reported by Marcushi et al. [22] using carbobenzoxy-PheArg-7-amido-4-methylcoumarin (z-FRMCA). For evaluation of the total proteolytic alkaline activity casein or azocasein (non-specific protease substrates) are applied [19, 36]. Enzyme kinetics studies include the determination of optimum $\mathrm{pH}, \mathrm{pH}$ stability, optimum temperature, thermostability, as well as kinetic parameters (Micahelis constant, $\mathrm{K}_{\mathrm{M}}$; maximal velocity, $\mathrm{V}_{\max }$ ) [21, 32, 35, 39-41]. The effect of inhibitors (phenylmethylsulfonyl fluoride, PMSF; ethylenediaminetetraacetic acid, EDTA; pepstatin; soybean trypsin inhibitor (SBTI) and iodoacetic acid), as well as activators $\left(\mathrm{CaCl}_{2}\right.$ and $\left.\mathrm{NaCl}\right)$ should be addressed [20, 22, 23, 30, 38]. Some authors [19-21, 25] also studied the effect of metal ions (e.g. $\mathrm{Al}, \mathrm{Ba}, \mathrm{Ca}, \mathrm{Cd}, \mathrm{Cu}, \mathrm{Fe}, \mathrm{Hg}, \mathrm{K}, \mathrm{Li}, \mathrm{Mn}, \mathrm{Pb}$, and
$\mathrm{Zn})$. The evaluation of these parameters is important since genetic variation within species together with adaptation to different environmental conditions have resulted in differences in the kinetic properties of fish proteases.

Protein concentration is usually determined by the Lowry [22, 30, 32, 34, 37] or Bradford methods [21-23, 36] using bovine serum albumin (BSA) as standard. These colorimetric assays have some disadvantages related to interferences, accuracy and poor sensitivity, however, they provide a fast and cheap determination of protein content. Purity, homogeneity and molecular mass of the extracted enzymes are studied by electrophoresis in polyacrylamide gel and zymography [19, 22-24, 30, 32, 34]. Isoelectric focusing (or electrofocusing) is used to separate proteins according to their isoelectric point (pI) [30, 42, 43]. Superior characterization is achieved with the analysis of $\mathrm{N}$-terminal amino acid sequence, using protein sequencers coupled to high performance liquid chromatography (HPLC) equipment [21, 25, $30,32,37]$. Mass spectrometry methods are now the most widely used for protein sequencing and identification, but Edman degradation remains a valuable tool for characterizing a protein's $N$-terminus [21, 22].

\section{Fish Protein Hydrolysates}

Fish discards resulting from traditional fish processing have been progressively recognized as a source of underutilized protein. In recent years, researchers have gathered efforts to maximize fish wastes by producing fish protein hydrolysates (FPH), which show high potential for applications such as food products or even pharmaceutical [4, 13, 44].

\section{Extraction of Fish Protein Hydrolysates}

Most studies rely on the application of proteolytic enzymes to break down fish protein and obtain hydrolysates (Table 2). In fact, this is considered a fast and controllable method and it has gained more attention among researchers due to the ability to produce hydrolysates, retaining their nutritional value. Ususally, during the enzymatic process, commercial enzymes (e.g. alcalase, flavourzyme, neutrase) are added to the protein samples [45-47]. In general, the study of the optimum conditions is based on the evaluation of the degree of hydrolysis (DH) [48].

Protein hydrolysates can be obtained by other methods than those using commercial enzymes. For example, autolysis which was reported by Samaranayaka and Li-Chan [43] prepared hydrolysates from Pacific hake fish used the high endogenous proteolytic activity from a parasitic infection. In parallel, FPH were produced by the addition of commercial enzymes (Validase ${ }^{\circledR}$ and Flavourzyme ${ }^{\circledR}$ ) which resulted in higher DH in comparison to the autolysis process. It is 
Table 2 Examples of methods and optimized conditions for the production of fish protein hydrolysates

\begin{tabular}{|c|c|c|c|c|c|c|c|c|c|}
\hline \multirow[t]{2}{*}{ Fish species } & \multirow[t]{2}{*}{ Organ } & \multirow[t]{2}{*}{ Extraction } & \multicolumn{4}{|c|}{ Optimized conditions } & \multirow[t]{2}{*}{ Yield (\%) } & \multirow[t]{2}{*}{$\mathrm{DH}(\%)$} & \multirow[t]{2}{*}{ References } \\
\hline & & & {$[\mathrm{E} / \mathrm{S}]$} & $\mathrm{PH}$ & $\mathrm{T}(\mathrm{h})$ & $\mathrm{T}\left({ }^{\circ} \mathrm{C}\right)$ & & & \\
\hline $\begin{array}{l}\text { Yellowfin tuna } \\
\text { (Thunnus } \\
\text { albacares) }\end{array}$ & Stomach & $\begin{array}{l}\text { Enzymatic } \\
\text { hydrolysis } \\
\text { (Alcalase) }\end{array}$ & $3.0 \%$ & 8.0 & 5.5 & 50 & - & 23 & {$[45]$} \\
\hline Tuna (Thunnus) & $\begin{array}{l}\text { Fish soluble } \\
\text { concentrate }\end{array}$ & $\begin{array}{l}\text { Enzymatic } \\
\text { hydrolysis } \\
\text { (Flavourzyme) }\end{array}$ & $5.0 \%$ & 6.0 & 6 & 45 & $68^{\mathrm{a}}$ & 62 & [147] \\
\hline $\begin{array}{l}\text { Cod (Gadus } \\
\text { morhua) }\end{array}$ & $\begin{array}{r}\text { Viscera and } \\
\text { Backbone }\end{array}$ & $\begin{array}{l}\text { Enzymatic } \\
\text { hydrolysis (Fla- } \\
\text { vourzyme) }\end{array}$ & $0.1 \%$ & - & 1 & 50 & - & $19.5-33.7$ & [46] \\
\hline $\begin{array}{l}\text { Pacific hake } \\
\text { (Merluccius } \\
\text { productus) }\end{array}$ & Fillets & Autolysis & - & 5.5 & 1 & 52 & $47.7^{\mathrm{a}}$ & - & [148] \\
\hline $\begin{array}{l}\text { Herring (Pellona } \\
\text { ditchelee) }\end{array}$ & Fillets & Autolysis & - & 5.0 & 1.5 & 50 & - & 40.2 & [149] \\
\hline $\begin{array}{l}\text { Nile tilapia } \\
\quad \text { (Oreochromis } \\
\text { niloticus) }\end{array}$ & Skin & $\begin{array}{l}\text { Thermal } \\
\text { hydrolysis } \\
\text { Enzymatic } \\
\text { hydrolysis } \\
\text { (894 alka- } \\
\text { line pro- } \\
\text { tease + papain) }\end{array}$ & ${ }_{300 \mathrm{U} / \mathrm{g}}$ & $\begin{array}{l}4.0 \\
10+6\end{array}$ & $\begin{array}{l}3 \\
0.25+0.25\end{array}$ & $\begin{array}{l}121 \\
50\end{array}$ & $\begin{array}{l}13 \\
14\end{array}$ & - & {$[50]$} \\
\hline $\begin{array}{l}\text { Sardinelle (Sar- } \\
\text { dinella aurita) } \\
\text { Zebra blenny } \\
\quad \text { (Salaria } \\
\text { basilisca) } \\
\text { Goby } \\
\text { (Zozterizessor } \\
\text { ophiocephalus) } \\
\text { Ray (Dasyatis } \\
\text { pastinaca) }\end{array}$ & Muscle & $\begin{array}{l}\text { Bacterial fer- } \\
\text { mentation }\end{array}$ & $200-400 \mathrm{U} / \mathrm{mL}$ & 8 & 24 & 37 & - & - & {$[60]$} \\
\hline $\begin{array}{l}\text { Carps (Labeo } \\
\text { rohita, Gibe- } \\
\text { lion catla) }\end{array}$ & Heads & $\begin{array}{l}\text { Bacterial fer- } \\
\text { mentation }\end{array}$ & - & - & 24 & 37 & - & 38.4 & {$[51]$} \\
\hline $\begin{array}{l}\text { Small-spotted } \\
\text { catshark } \\
\text { (Scyliorhinus } \\
\text { canicular) }\end{array}$ & Muscle & $\begin{array}{c}\text { Enzymatic } \\
\text { hydrolysis } \\
\text { (Alcalase/ } \\
\text { Esperase) }\end{array}$ & $0.5 \%$ & $9.40 / 8.90$ & 6 & $64.6 / 60.8$ & - & $26.3 / 30.7$ & [47] \\
\hline
\end{tabular}

$D H$ degree of hydrolysis, $[E / S]$ enzyme to substrate ratio

${ }^{\text {a }}$ Yield under optimal conditions

noteworthy that autolysis is regarded as an economical and simple process to obtain FPH. However, the studies based on this method are still scarce due to the impossibility to control factors like the type and amount of enzymes [49].

Wang et al. [50] applied thermal hydrolysis for the hydrolysis of tilapia skin. In this study, no significant differences for the yield of the resultant hydrolysates were observed between thermal and enzymatic hydrolysis. Despite this, the enzymatic process was recommended since it needs less time and milder conditions to obtain hydrolysates.

More recently, bacterial fermentation has been proposed for the generation of fish hydrolysates. Three different proteolytic lactic acid bacteria (Enterococcus faecium, Pediococcus acidilactici and Pediococcus acidilactici) were reported for the generation of protein hydrolysates from fish heads [51]. After the fermentation process, it was found that the DH ranged between 29.0 and $38.4 \%$ for the considered lactic acid bacteria (LAB). Furthermore, the hydrolysates obtained by this process showed promising bioactive properties (antioxidant and antimicrobial) turning them suitable to be used in food industry.

Nowadays, research on FPH is mainly focused on bioactive peptides due to their reported biological functions with potential applications in the food industry and benefits to 
human health $[44,52]$. Their potential bioactivity is strongly affected by their molecular weight and amino acid sequence [53]. After producing the FPH, bioactive peptides can be obtained through purification procedures. Within the available processes, ultra and nanofiltration, ion-exchange membranes and reverse-phase HPLC have been applied for the purification of protein hydrolysates [54]. Nevertheless, it is worthy to mention that FPH could themselves be used as bioactive compounds (bioactive peptides) although it has been proven that biological activity is enhanced after the purification of the hydrolysates [55].

\section{Characterization of Fish Protein Hydrolysates}

Protein hydrolysates generated from marine sources show a variety of potential applications based on their unique properties. Table 3 resumes the functional properties typically evaluated for FPH such as solubility, water and oil absorption, and surface-active properties (like emulsifying and foaming properties).

Fish protein hydrolysates show a remarkable solubility ( $>40 \%$ ) which is comparatively higher than native proteins. In fact, the degradation of proteins leads to smaller peptides presenting an improved solubility [56].

Regarded as surface properties, foam expansion or capacity and foam stability give a better understanding about the transportation, penetration and rearrangement of molecules at the air-water interface [57]. An overview of the foaming properties revealed that foam expansion can be found at values from 17 to $200 \%$, while foam stability is ranged from 4 to $100 \%$ [58-64].

Proteins are known for being excellent emulsifiers due to an amphipathic structure which promotes their absorption at the oil-water interface [65]. Jemil et al. [60] showed that the emulsifying activity of protein hydrolysate prepared from sardinelle decreased from 47.6 to $8.2 \mathrm{~m}^{2} / \mathrm{g}$ after increasing the protein concentration from 0.5 to $2 \%(\mathrm{w} / \mathrm{v})$. Higher concentrations of proteins may lead to problems such as aggregation, precipitation and gelation. Besides this, an increased viscosity affects the interactions between proteins to form the interfacial membrane around oil droplets [61].

Hydrodynamic properties such as water and oil holding capacities (WHC and OHC, respectively) are also typically considered for the characterisation of protein hydrolysates. In general, fish protein hydrolysates reveal excellent WHC justified by the increased concentration of polar groups such as $\mathrm{COOH}$ and $\mathrm{NH}_{2}$ resulting from hydrolysis [66]. Taheri et al. [63] reported a WHC of $5.1 \mathrm{~mL} / \mathrm{g}$ for FPH which was significantly higher than hydrolysates resultant from poultry protein hydrolysates (PPH), $2.8 \mathrm{~mL} / \mathrm{g}$. The amino acid composition of both protein hydrolysate sources revealed also that FPH contained more glutamic and aspartic acids than $\mathrm{PPH}$, indicating the presence of more hydrophilic groups, which favours water absorption. $\mathrm{OHC}$ reflects the capacity of proteins to absorb and retain oil [67]. OHC is usually related to emulsifying capacity and it can be influenced by bulk density and DH [68].

Despite the diversity of the bioactive functions, this part of the review will be focused on the antioxidative and antimicrobial activity exhibited by the bioactive peptides derived from FPH.

For the evaluation of antioxidant activity some chemical methods could be considered. The most common antioxidative tests are 1,1-diphenyl-2-picryl hydrazyl (DPPH) free radical scavenging, hydroxyl radical scavenging, superoxide anion radicals scavenging, and inhibition of lipid peroxidation [54, 69]. Ktari and colleagues [61] evaluated the antioxidant properties of zebra blenny protein hydrolysates prepared with different crude protease extracts. Scavenging activity was measured, revealing high antioxidant activity against DPPH. The results showed that scavenging activity increased with the hydrolysate concentration until a maximum of $76.6 \%$ at $6 \mathrm{mg} /$ $\mathrm{mL}$. Significant differences between radical-scavenging activities were observed for each of the hydrolysates under analysis. According to the authors, this may be attributed to the amino acid composition of peptides within protein hydrolysates. In fact, hydrolysates that contained a higher concentration of hydrophobic amino acids were associated with the higher antioxidant activity. These results were in line with the work presented by other authors [58], who reported a scavenging activity against DPPH of $89 \%$ at $6 \mathrm{mg} / \mathrm{mL}$ for sardinelle protein hydrolysates. The antioxidant capacity of the hydrolysate could also be improved by the presence of aromatic amino acids, such as histidine. It was concluded that histidine-containing peptides show the ability to react with free radicals leading to the obtainment of more stable products [64].

Despite these findings, the above mentioned bioactive peptides have revealed a lower antioxidant capacity in comparison to butylated hydroxyanisole (BHA) which is one of the most commonly used synthetic antioxidants. As so, the use of these bioactive compounds derived from fish sources, as an alternative to BHA, without compromising the effectiveness of the antioxidant properties remains a challenge to researchers.

In addition, fish protein hydrolysates have also been regarded as promising natural sources for antimicrobial agents. Still, the number of studies on the antimicrobial activity of these hydrolysates are scarce. Jemil et al. [60] evaluated the antibacterial activity of protein hydrolysates prepared from different fish species towards some Grampositive and Gram-negative bacteria. Among the FPH tested, hydrolysates obtained from sardinelle were the ones with stronger inhibitory activity assessed by the evaluation of the inhibition zone. Moreover, these hydrolysates were 


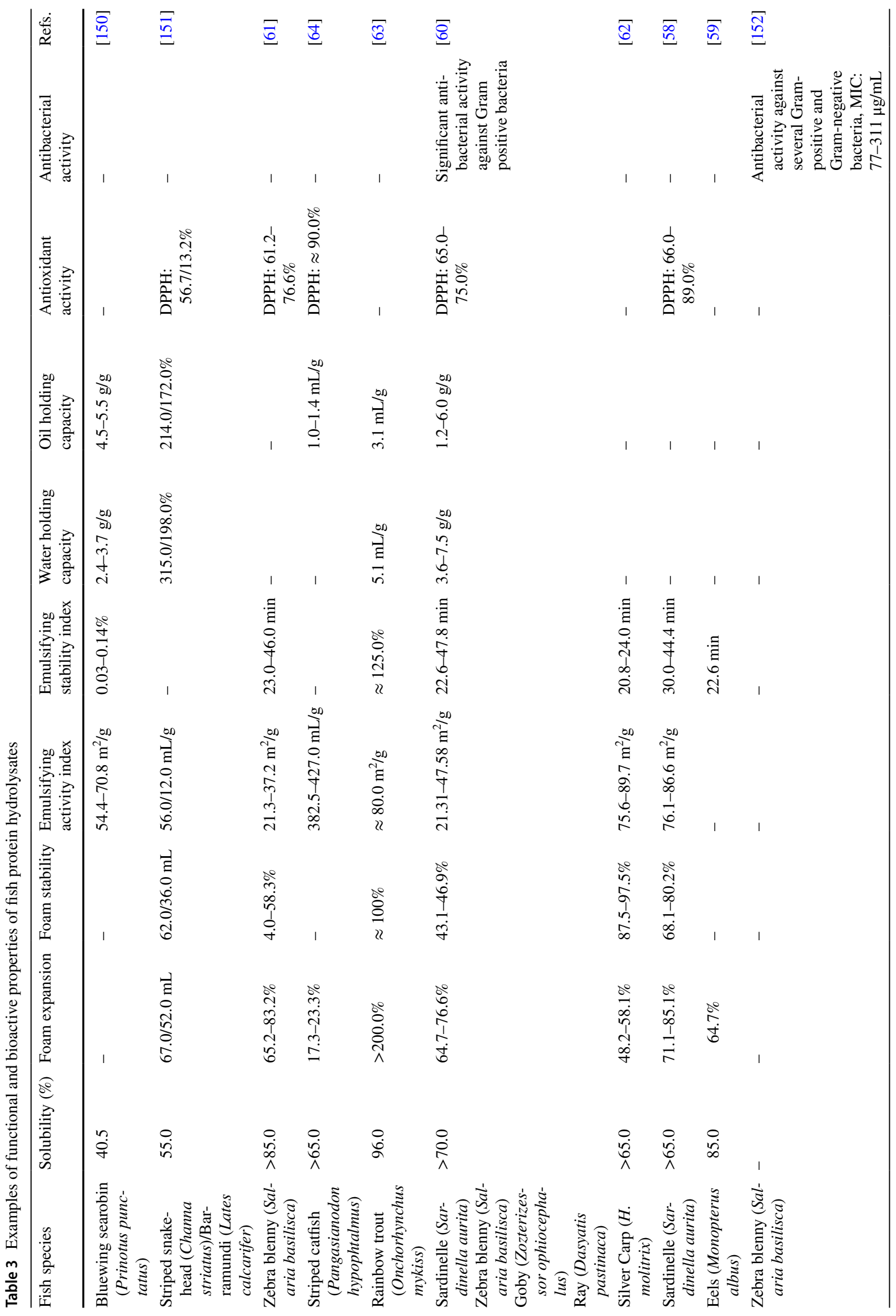




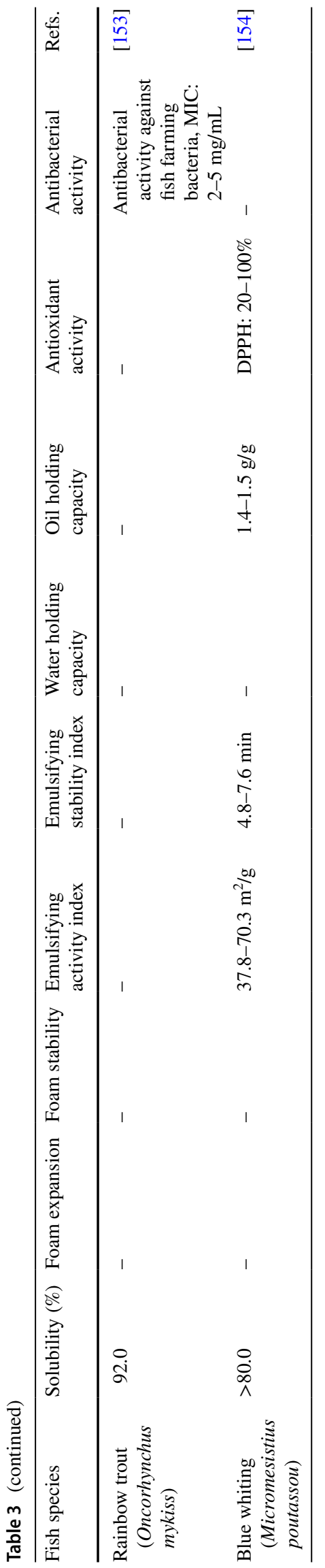

more effective against the Gram-positive bacteria rather than Gram-negative which are known for being more resistant.

Antimicrobial activity of peptides appears to be affected by some factors like hydrophobicity, molecular weight and the proportion of polar groups. Regarding the fish hydrolysates, the biological activity of the peptides released is considerably influenced by the DH. This influence was studied by Tanuja and colleagues [64] that evaluated the inhibitory effect on 14 different bacteria, by hydrolysates prepared from trout with DH of 10, 20, 25 and 30\%. From the results, it was demonstrated that antimicrobial effect was more pronounced for hydrolysates with higher DH (30\%). Also, the resultant peptides showed a higher percentage of hydrophobic amino acids, which may improve the interaction with the bacterial membrane and therefore enable the antibacterial activity of the hydrolysate [70].

FPH have highlighted potential applications in food systems either as natural additive or emulsifying agent, but also in pharmaceutical and cosmetic industry [59-61, 64]. The incorporation of FPH into different food systems like cereals, fish, meat and dessert products has been reported in a previous review [2]. Still, despite the potential applications that have been attributed to FPH, there is insufficient information about the performance and stability of these hydrolysates in the final products. It also deserves to be mentioned that most of the investigation made so far on FPH bioactivity have been carried out in vitro. Therefore it is recommended that the outcomes showed so far should be confirmed by further in vivo studies to ensure health sustaining products derived from fish hydrolysates.

\section{Collagen and Gelatin}

Collagen is the dominant structural protein of extracellular matrix found in animal body [71]. Its structure consists in three helical polypeptide chains with a repetitive tripeptide unit, Glycine- $\mathrm{X}-\mathrm{Y}$, where $\mathrm{X}$ and $\mathrm{Y}$ positions are generally occupied by proline (Pro) and hydroxyproline (Hyp), respectively [72]. Glycine represents about one-third of the total residues except in the $\mathrm{N}$ - and $\mathrm{C}$-terminal regions, called telopeptides, that are composed by lysine and hydroxylysine residues [73]. Curiously, collagen is the only mammalian protein characterized by large amounts of hydroxyproline and hydroxylysine, and high content of the total imino acid ${ }^{1}$ (Pro and Hyp) [74].

Until now, at least 29 different types of collagen from animal tissues, with a specific amino acid sequence, protein structure and function have been reported. Among these

\footnotetext{
${ }^{1}$ Is an obsolete term (IUPAC, 1997 "imino acids,"). In this review
} we will save the imino acid designation, for standardizing purposes. 


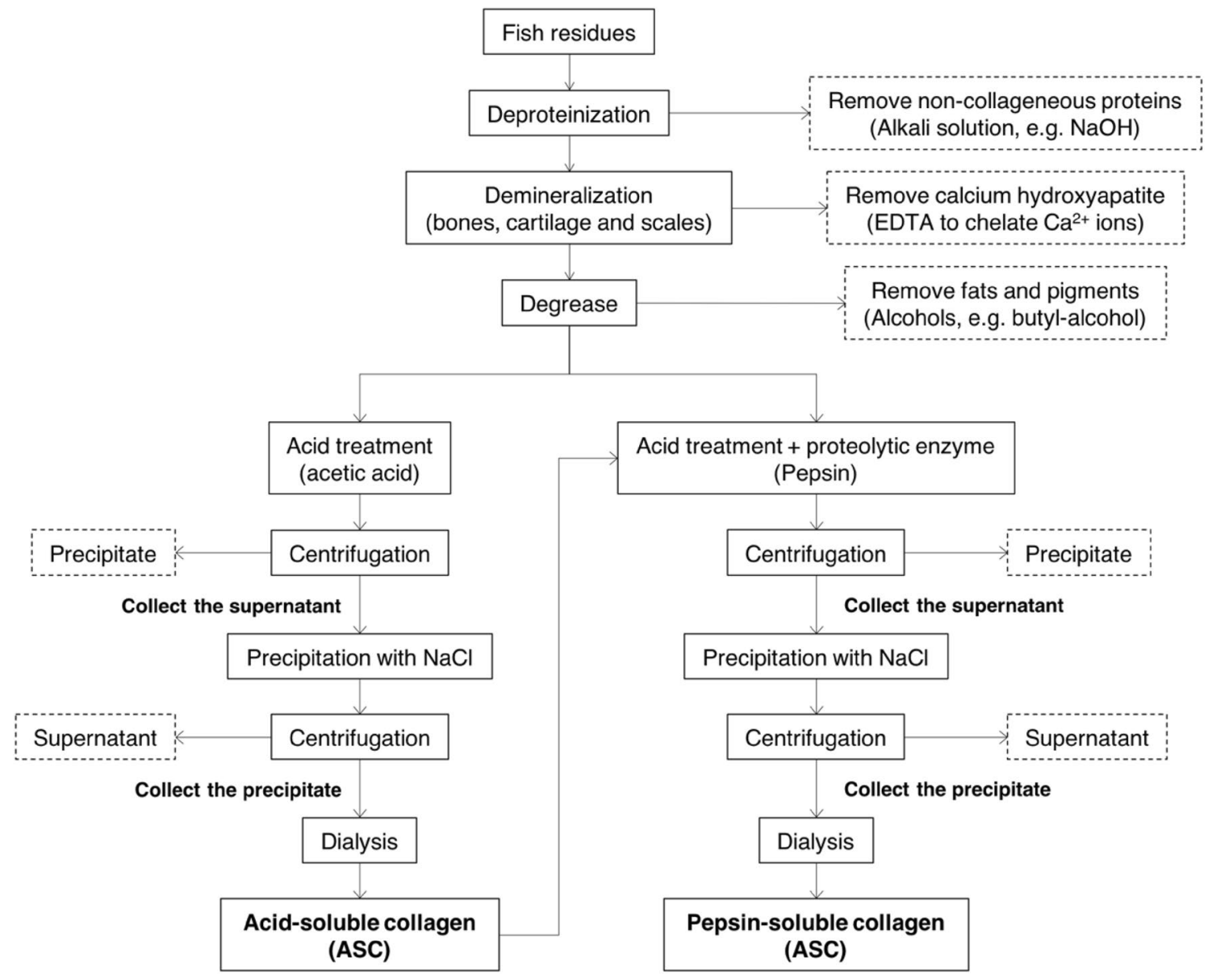

Fig. 2 A flowchart for the main procedure for the isolation of collagen from different morphological parts of fish residues. The extraction procedure comprises the chemical pre-treatment and acid-soluble collagen (ASC) method and pepsin-soluble collagen (PSC) method

various types, type-I collagen is the most common form and it can be found in connective tissue such as skin, tendons and bones [6].

Gelatin belongs to a class of protein fractions that are derived from collagen, by thermal hydrolysis which involve the breakage of hydrogen bonds between polypeptide chains of collagen molecules. As so, collagen and gelatin are two different forms of the same macromolecule [74, 75].

Traditionally, collagen and gelatin have been obtained from mammalian animals (e.g. pig, cow and poultry). However, due to its potential risks for viral and prion contaminations, these sources have been avoided [71].

In search for new sources to obtain collagen and gelatin, researchers have drawn their attention to fish by-products, namely skin, scales, bones, swim bladders and fins [76-80]. These materials contain different variants of collagen. TypeI collagen is the most common variant and can be found in the connective tissues such as skin and bones [81].

Collagen extracted from fish by-products has been considered attractive for cosmeceuticals [71], biomedical applications, as a scaffolding material and tissue engineering [82,
83], and for agriculture purpose [84]. Due to its characteristics, gelatin has most significant application in the food industry field $[75,85]$, pharmaceutical and cosmetics industries $[73,75]$.

\section{Extraction Methods}

The extraction of collagen from fish by-products consists of three main stages: pretreatment of the raw material, isolation of the product of interest and purification (see Fig. 2) [74]. The pretreatment stage can include procedures such as separation of animal parts, size reduction, and chemical pretreatment-deproteinization, demineralization and degreasing. For example, in the case of scales and bones, a demineralization step is usually required to remove $\mathrm{Ca}$ or other inorganic materials from the raw material $[6,86,87]$.

After pretreatment the extraction of collagen is usually carried out in acidic solutions in a procedure referred to acid soluble collagen (ASC). Due to its crosslinks, collagen has lower solubilization in acidic conditions and consequently lower yields under these conditions [73]. To improve the 
collagen extraction, an enzymatic hydrolysis step was proposed. Pepsin is usually added to cleave some peptide bonds, resulting in a higher efficacy in collagen extraction (pepsin soluble collagen method, PSC) [88, 89].

As for the gelatin extraction two methods are commonly used: acid or alkaline process, which results in type A and type B gelatin, respectively. The acid process involves the pretreatment of raw materials with an acid solution followed by an extraction in acid medium. As for the alkaline process, the pretreatment step is carried out with an alkaline solution, in most cases followed by neutralization, so the extraction may be carried out in different medium (alkaline, neutral or acid) [89]. Moreover, the acidic treatment is most suitable for the less covalently crosslinked collagens while the alkaline process is recommended for the more complex collagens [74].

Following the extraction of collagen/gelatin a centrifugation step is performed. In the end the supernatant is collected and precipitated with $\mathrm{NaCl}$ being redissolved in acetic acid. Finally, samples are submitted to dialysis in order to purify the final product.

In Table 4 are listed some of the most recent studies regarding the extraction of collagen and gelatin from fish by-products, with special emphasis to the extraction conditions and characterization of these macromolecules.

In the extraction of collagen, organic acids (like acetic, citric and lactic) are commonly used, being more efficient than inorganic ones due to the ability to enhance the solubility of collagen during extraction [6].

As seen in Table 4, the yield of the final product can vary significantly with the process conditions, but also with raw materials considered for extraction. Sinthusamran et al. [90] described the extraction of collagen from two by-products of seabass, skin and swim bladder, following the ASC procedure. The authors verified that the swim bladder gave a higher yield compared to the skin $(85.3 \%$ for swim bladder and $58.1 \%$ for skin). According to the authors, the swim bladder exhibits less cross-linked collagen, which facilitated the extraction process. In another study [86], a higher extraction yield of type I collagen was obtained from rohu $(2.7 \%$ $\mathrm{w} / \mathrm{w})$ compared to the one from Carp catla $(1.7 \% \mathrm{w} / \mathrm{w})$.

The PSC procedure leads to significantly higher yields in collagen extraction (Table 4). Pepsin is responsible for the specific cleavage at the telopeptide region of collagen allowing a better control of the process which implies a considerable reduction of the waste [79, 91, 92]. Despite the improvement in the use of pepsin, the cost of enzyme may represent a disadvantage for the application of this process. Kaewdang et al. [79] have proposed the application of endogenous enzymes from crude stomach extract (mainly pepsin) for the release of collagen from swim bladders of yellow-fish tuna. The comparison of ASC and PSC procedures resulted in yields of 1.07 and $12.10 \%$, respectively.
Endogenous enzymes from stomach were successfully used for the extraction of collagen from fish by-products, demonstrating the enormous potential of marine discards.

Other approaches have also been considered for the extraction of collagen. Ali et al. [93] studied the extraction efficiency of collagen from the skin of golden carp by using ultrasound treatment in conjugation with acid and pepsin soluble collagen procedures. The use of ultrasound in conjugation with acidic or enzymatic methods resulted in a marked increase in collagen yields. This effect was more pronounced in the ASC procedure (up to 1.57-fold). The cavitation effect promoted by the ultrasounds helps to loosen the fish matrix, improving mass transfer, thus enhancing the penetration of solvent and the extraction yield. However, ultrasound extraction has limited industrial applications due to its expensive scale-up.

A combination of physical methods like ultrasounds and vigorous mechanical mixing with conventional procedures (named IASC) was applied for collagen extraction from jellyfish tissue [94]. By comparison, the IASC process resulted in seven times higher collagen extraction than ASC and two times higher than PSC, contributing to a significant reduction in the time of extraction. Despite these results the use of physical methods may be disadvantageous for industrial purposes due to the high energetic costs.

As mentioned before, gelatin extraction protocols rely on the use of alkaline or acid treatment followed by extraction with distilled water at relatively high temperature $\left(45-80{ }^{\circ} \mathrm{C}\right)$. The use of enzymes can also be included to achieve higher gelatin extraction yields [95, 96]. Zhang et al. [97] described the extraction of gelatin from the skin of spiny dogfish using a pretreatment with alcalase. According to the authors enzymes are effective under mild reaction conditions promoting the formation of high-quality gelatin in comparison to chemical hydrolysis.

Ultrasounds methodology has also been investigated for the extraction of gelatin from marine sources. Gelatin was obtained from the skin of golden carp according to different procedures with and without acid pretreatment and ultrasonication [92]. The authors were able to observe that the highest yield $(62.12 \%)$ derived from the treatment with sulphuric and acetic acids followed by ultrasounds extraction.

\section{Characterization Methods}

After extraction, it is important to study and evaluate the characteristics of collagen and gelatin to determine further applications [72].

Fourier-transform infrared (FT-IR) spectroscopy is a simple method to investigate the functional groups and to discuss the collagen triple helical structure [72]. Over the years, this technique has been widely used to examine the secondary structure of proteins including collagen 
Table 4 Examples of extraction and characterization methods for collagen and gelation from fish by-products

\begin{tabular}{|c|c|c|c|c|c|c|}
\hline Fish species & Part used & Product & Extraction & Yield (\%) & Characterization & Refs. \\
\hline $\begin{array}{l}\text { Seabass (Lates cal- } \\
\quad \text { carifer) }\end{array}$ & $\begin{array}{l}\text { Swim bladder and } \\
\text { skin }\end{array}$ & Collagen & $\begin{array}{l}\text { ASC }-0.5 \mathrm{M} \text { acetic } \\
\text { acid; } 48 \mathrm{~h}\end{array}$ & $\begin{array}{l}\text { Swim blad- } \\
\text { der-58.1\% (dwb) } \\
\text { Skin- } 85.3 \%(d w b)\end{array}$ & $\begin{array}{l}\text { Amino acid } \\
\text { SDS-PAGE } \\
\text { FTIR } \\
\text { DSC }\end{array}$ & {$[90]$} \\
\hline $\begin{array}{l}\text { Yellowfin tune } \\
\text { (Thunnus albac- } \\
\text { ares) }\end{array}$ & Swim bladders & Collagen & $\begin{array}{l}\text { ASC }-0.5 \mathrm{M} \text { acetic } \\
\text { acid; } 48 \mathrm{~h} \\
\text { PSC-0.5 M acetic } \\
\text { acid + crude stom- } \\
\text { ach extract; } 48 \mathrm{~h}\end{array}$ & $\begin{array}{l}\text { ASC: } 1.07 \%(\mathrm{dwb}) \\
\text { PSC: } 12.10 \%(\mathrm{dwb})\end{array}$ & $\begin{array}{l}\text { Amino acid } \\
\text { SDS-PAGE } \\
\text { FTIR } \\
\text { DSC }\end{array}$ & [79] \\
\hline $\begin{array}{l}\text { Nothern Pike (Esox } \\
\text { lucius) }\end{array}$ & Scales & Collagen & $\begin{array}{l}\text { ASC }-0-5 \mathrm{M} \text { acetic } \\
\text { acid; } 48 \mathrm{~h} \\
\text { PSC-0.5 M acetic } \\
\text { acid }+ \text { pepsin } \\
1 \%(\mathrm{w} / \mathrm{w}) ; 48 \mathrm{~h}\end{array}$ & - & $\begin{array}{l}\text { SEM } \\
\text { FTIR } \\
\text { Amino acid } \\
\text { SDS-PAGE } \\
\text { DSC } \\
\text { Mechanical proper- } \\
\text { ties }\end{array}$ & [106] \\
\hline $\begin{array}{l}\text { Barbel (Barbus cal- } \\
\quad \text { lensis) }\end{array}$ & Skin & Gelatin & $\begin{array}{l}\text { Alkaline pro- } \\
\text { cess- } 0.05 \mathrm{M} \\
\mathrm{NaOH}+\text { crude acid } \\
\text { protease extract; } \\
48 \mathrm{~h}\end{array}$ & $8.36 \%(w w b)$ & $\begin{array}{l}\text { Amino acid } \\
\text { SDS-PAGE } \\
\text { Functional proper- } \\
\text { ties }\end{array}$ & [95] \\
\hline $\begin{array}{l}\text { Squid (Loligo vul- } \\
\text { garis) }\end{array}$ & Skin & Gelatin & $\begin{array}{l}\text { Alkaline pro- } \\
\text { cess-0.05 M } \\
\mathrm{NaOH}+\text { pepsin; } \\
48 \mathrm{~h}\end{array}$ & $6.82 \%(w w b)$ & $\begin{array}{l}\text { Amino acid } \\
\text { FTIR } \\
\text { Functional proper- } \\
\text { ties }\end{array}$ & [96] \\
\hline $\begin{array}{l}\text { Carp (Cyprinus } \\
\text { carpio) }\end{array}$ & Scales & Collagen & $\begin{array}{l}\text { ASC }-0.5 \mathrm{M} \text { acetic } \\
\text { acid; } 48 \mathrm{~h}\end{array}$ & $9.79 \%(w w b)$ & $\begin{array}{l}\text { FTIR } \\
\text { SDS-PAGE }\end{array}$ & {$[84]$} \\
\hline $\begin{array}{l}\text { Tilapia (Oreochromis } \\
\text { niloticus) and chan- } \\
\text { nel catfish (Ictalu- } \\
\text { rus punctatus) }\end{array}$ & Skin & Collagen and Gelatin & $\begin{array}{l}\text { ASC_lactic acid } \\
60 \%(\mathrm{v} / \mathrm{v}) ; 46 \mathrm{~h} \\
\text { PSC-lactic acid } \\
50 \%(\mathrm{v} / \mathrm{v})+\text { pepsin; } \\
17 \mathrm{~h} \\
\text { Acid process- } 0.2 \% \\
\text { sulphuric } \\
\text { acid + } 0.2 \% \text { citric } \\
\text { acid; water at } \\
45^{\circ} \mathrm{C}, 12 \mathrm{~h}\end{array}$ & $\begin{array}{l}\text { ASC: } 25.6-25.9 \% \\
\text { (dwb) } \\
\text { PSC: } 21.8-28.8 \% \\
\text { (dwb) } \\
\text { Acid process: } \\
\text { 80.6-93.1\% (dwb) }\end{array}$ & $\begin{array}{l}\text { FTIR } \\
\text { SDS-PAGE } \\
\text { SEM }\end{array}$ & [100] \\
\hline Salmon (salmo salar) & Skin & Gelatin & $\begin{array}{l}\text { Acid pro- } \\
\text { cess- } 0.05 \mathrm{M} \\
\text { acetic acid at } 60{ }^{\circ} \mathrm{C}\end{array}$ & - & $\begin{array}{l}\text { Amino acid } \\
\text { SDS-PAGE } \\
\text { X-ray diffraction }\end{array}$ & [103] \\
\hline $\begin{array}{l}\text { Snakehead (Channa } \\
\text { Micropeltes) }\end{array}$ & Scales & Collagen & $\begin{array}{l}\text { ASC }-0.5 \mathrm{M} \text { acetic } \\
\text { acid; } 48 \mathrm{~h}\end{array}$ & - & $\begin{array}{l}\text { SEM } \\
\text { FTIR } \\
\text { NMR }\end{array}$ & {$[87]$} \\
\hline $\begin{array}{l}\text { Antarctic (Kondako- } \\
\text { via longimana) and } \\
\text { Sub-Antarctic (Illex } \\
\text { argentinus) squid }\end{array}$ & Skin & Collagen & $\begin{array}{l}\text { ASC }-0.5 \mathrm{M} \text { acetic } \\
\text { acid; } 72 \mathrm{~h} \\
\text { PSC-0.5 M acetic } \\
\text { acid + pepsin } \\
3.3 \mathrm{mg} ; 72 \mathrm{~h}\end{array}$ & $\begin{array}{l}\text { ASC: } 0.81-1.05 \% \\
\text { (wwb) } \\
\text { PSC: } 0.88-3.26 \% \\
\text { (wwb) }\end{array}$ & $\begin{array}{l}\text { FTIR } \\
\text { DSC } \\
\text { Amino acid } \\
\text { SDS-PAGE } \\
\text { SEM } \\
\text { Mechanical proper- } \\
\text { ties }\end{array}$ & {$[91]$} \\
\hline Carp (Catla catla) & Scales & Collagen & $\begin{array}{l}\text { ASC }-0.5 \mathrm{M} \text { acetic } \\
\text { acid; } 72 \mathrm{~h} \\
\text { PSC-0.5 M acetic } \\
\text { acid + pepsin } 0.5 \% \\
(\mathrm{w} / \mathrm{v}) ; 48 \mathrm{~h}\end{array}$ & $\begin{array}{l}\text { ASC: } 1.7-2.7 \% \\
\text { (dwb) } \\
\text { PSC: } 1.48-2.26 \% \\
\text { (dwb) }\end{array}$ & $\begin{array}{l}\text { SDS-PAGE } \\
\text { Amino acid } \\
\text { FTIR } \\
\text { SEM } \\
\text { DSC }\end{array}$ & {$[86]$} \\
\hline $\begin{array}{l}\text { Kumakuma (Brachy- } \\
\text { platystoma filamen- } \\
\text { tosum }\end{array}$ & Skin & Gelatin & $\begin{array}{l}\text { Alkaline pro- } \\
\text { cess-0.3 M } \\
\mathrm{NaOH} \text {; water at } \\
58{ }^{\circ} \mathrm{C}, 6 \mathrm{~h}\end{array}$ & $19.7 \%(w w b)$ & $\begin{array}{l}\text { Amino acid } \\
\text { SEM } \\
\text { Functional proper- } \\
\quad \text { ties }\end{array}$ & [108] \\
\hline
\end{tabular}


Table 4 (continued)

\begin{tabular}{|c|c|c|c|c|c|c|}
\hline Fish species & Part used & Product & Extraction & Yield (\%) & Characterization & Refs. \\
\hline $\begin{array}{l}\text { Tilapia (Oreochromis } \\
\text { niloticus) }\end{array}$ & Skin & Collagen & $\begin{array}{l}\text { ASC-0.5 M acetic } \\
\text { acid } \\
\text { PSC-0.5 M acetic } \\
\text { acid + pepsin } 0.5 \% \\
(\mathrm{w} / \mathrm{w})\end{array}$ & - & $\begin{array}{l}\text { Amino acid } \\
\text { CD } \\
\text { X-ray diffraction } \\
\text { FTIR } \\
\text { SDS-PAGE } \\
\text { SEM }\end{array}$ & [104] \\
\hline $\begin{array}{l}\text { Tilapia (Oreochromis } \\
\text { niloticus) }\end{array}$ & Skin & Collagen & $\begin{array}{l}\text { ASC-0.5 M acetic } \\
\text { acid; } 48 \mathrm{~h} \\
\text { PSC-0.5 M acetic } \\
\text { acid + pepsin } 0.1 \% \\
(\mathrm{w} / \mathrm{v}) ; 48 \mathrm{~h}\end{array}$ & $\begin{array}{l}\text { ASC: } 19.80 \%(\mathrm{dwb}) \\
\text { PSC: } 20.03 \%(\mathrm{dwb})\end{array}$ & $\begin{array}{l}\text { Amino acid } \\
\text { SDS-PAGE } \\
\text { FTIR } \\
\text { SEM }\end{array}$ & [107] \\
\hline $\begin{array}{l}\text { Carp (Probarbus } \\
\text { Jullieni) }\end{array}$ & Skin & Collagen & $\begin{array}{l}\text { ASC- }-0.5 \mathrm{M} \text { acetic } \\
\text { acid; } 48 \mathrm{~h} \\
\text { PSC-0.5 M acetic } \\
\text { acid + pepsin } 1 \% \\
\text { (w/v); } 48 \mathrm{~h} \\
\text { UASC-ultra- } \\
\text { sonication } \\
\text { (30 min) + ASC } \\
\text { UPSC-ultrasonica- } \\
\text { tion (30 min) + PSC }\end{array}$ & $\begin{array}{l}\text { ASC: } 51.90 \%(\mathrm{dwb}) \\
\text { PSC: } 79.27 \%(\mathrm{dwb}) \\
\text { UASC: } 81.53 \% \\
\text { (dwb) } \\
\text { UPSC: } 94.88 \% \\
\text { (dwb) }\end{array}$ & $\begin{array}{l}\text { SDS-PAGE } \\
\text { Amino acid } \\
\text { FTIR } \\
\text { DSC } \\
\text { CD }\end{array}$ & [92] \\
\hline $\begin{array}{l}\text { Jellyfish (Acromitus } \\
\text { hardenbergi) }\end{array}$ & Tissue & Collagen & $\begin{array}{l}\text { ASC- }-0.5 \mathrm{M} \text { acetic } \\
\text { acid; } 72 \mathrm{~h} \\
\text { PSC-0.5 M acetic } \\
\text { acid }+ \text { pepsin } 10 \% \\
(\mathrm{w} / \mathrm{v}) ; 48 \mathrm{~h} \\
\text { IASC-0.5 M acetic } \\
\text { acid }+ \text { ultrasonica- } \\
\text { tion }(15 \text { min })+\text { vig- } \\
\text { orous mixing }(1 \mathrm{~h})\end{array}$ & $\begin{array}{l}\text { ASC: } \sim 6 \%(\mathrm{dwb}) \\
\text { PSC: } \sim 20 \%(\mathrm{dwb}) \\
\text { IASC: } 37.08-40.20 \% \\
\quad(\mathrm{dwb})\end{array}$ & $\begin{array}{l}\text { SDS-PAGE } \\
\text { Amino acid }\end{array}$ & [94] \\
\hline $\begin{array}{l}\text { Spiny dogfish (Squa- } \\
\text { lus acanthias) }\end{array}$ & Skin & Gelatin & $\begin{array}{l}\text { Alcalase, } \\
2.1 \mathrm{~h}+\text { water at } \\
50^{\circ} \mathrm{C}, 4.6 \mathrm{~h}\end{array}$ & - & $\begin{array}{l}\text { Amino acid } \\
\text { FTIR } \\
\text { TGA }\end{array}$ & [97] \\
\hline $\begin{array}{l}\text { Carp (Probarbus } \\
\text { jullieni) }\end{array}$ & Skin & Gelatin & $\begin{array}{l}0.02 \mathrm{M} \text { sulphuric } \\
\text { acid }+0.05 \mathrm{M} \text { ace- } \\
\text { tic acid; ultrasoni- } \\
\text { cation }(30 \mathrm{~min}) \\
\text { water at } 55^{\circ} \mathrm{C}, 6 \mathrm{~h}\end{array}$ & $62.12 \%$ & $\begin{array}{l}\text { Amino acid } \\
\text { SDS-PAGE } \\
\text { FTIR }\end{array}$ & [93] \\
\hline
\end{tabular}

$A S C$ acid-soluble collagen, $P S C$ pepsin-soluble collagen, $d w b$ dry weight basis, $w w b$ wet weight basis

and gelatin, through the absorption in the amide I region $\left(1600-1700 \mathrm{~cm}^{-1}\right)[98,99]$. Although the infrared spectra of these macromolecules are quite similar there are some differences that can be pointed out. Gelatin derived from fish skin presented a FT-IR spectra slightly different from ASC and PSC. The lower intensity of amides I, II, III bands suggested a higher degree of disorder in gelatin and the loss of most of the triple helix structure originally exhibited by collagen [100]. The triple helical structure of collagen is also evaluated through FT-IR absorption ratio of amide III to $1450 \mathrm{~cm}^{-1}$ band, which should be close to 1 for native collagen $[101,102]$ and for collagen extracts [93]. According to the authors, these results confirmed that ultrasound or pepsin treatment had no impact on the native structure of collagen.
X-ray diffraction (XRD) and circular dichroism (CD) are two powerful techniques used to assess the helical content of a collagen sample. Díaz-Calderón et al. [103] have studied the influence of extraction variables ( $\mathrm{pH}$ and time) on the structure of salmon gelatin. X-ray diffraction patterns of the extracts showed the presence of two characteristic peaks. The first peak is related to the triple helix structure, indicating the distance between the molecular chains while the second peak indicates the distance between skeletons. The authors were able to establish a correlation between the intensity of the first peak and the extraction conditions. Therefore, a higher intensity was found for mild conditions (pH 5/2 h), which results in gelatin with higher triple helix content $(9.0 \%)$. On the other hand, the most aggressive conditions ( $\mathrm{pH} 3 / 5 \mathrm{~h}$ ) have registered a less intense peak and a 
lower triple helix content (3.1\%). In another study [104], CD was applied to evaluate the secondary structure of ASC and PSC from the skin of Nile Tilapia. CD measures the differences in absorption of left-rotated and right-rotated circularly polarized light. The typical CD spectrum of collagen shows a positive and negative peak whose ratio (Rpn) ranges from 0.12 to 0.15 [105]. Both, tilapia skin ASC and PSC showed XRD diagrams characteristic of collagen, while CD spectra showed Rpn values of 0.12 and 0.13 , respectively. As so, it was concluded that ASC and PSC maintained the integrity of the triple helical structure.

Collagen and gelatin extracts are commonly studied for their amino acid composition. The amino acid analysis is achieved by a protein hydrolysis, comprising steps such as amino acid separation, identification and quantification by HPLC. As expected, glycine (225-331 residues/1000 residues) is reported as the most abundant amino acid, followed by alanine $[79,91,106]$.

The thermal stability of collagen is usually described by the denaturation temperature $\left(\mathrm{T}_{\mathrm{d}}\right)$ and is frequently determined by differential scanning calorimetry (DSC). Sinthusamran et al. [90], compared the thermal stability of ASC extracted from skin and swim bladder of seabass. The results showed that swim bladder gave collagen with higher thermal stability $\left(\mathrm{T}_{\max }=35.02{ }^{\circ} \mathrm{C}\right)$, than the one obtained from skin $\left(\mathrm{T}_{\max }=33.33^{\circ} \mathrm{C}\right)$. The differences in $\mathrm{T}_{\max }$ between ASCs were correlated with the imino acid content, which was slightly higher for the swim bladder extract. A similar conclusion was drawn after $\mathrm{T}_{\max }$ analysis of ASC and PSC from the skin of golden carp. A higher $\mathrm{T}_{\max }$ value was found for PSC and UPSC due to the higher content of imino acids which might contribute to a better stabilization of the triple helix structure [93].

Sodium dodecyl sulfate polyacrylamide gel electrophoresis (SDS-PAGE), a variant of polyacrylamide gel electrophoresis, is often used for the characterization of collagen and gelatin extracts (Table 4). The SDS-PAGE patterns of these macromolecules are usually composed by two different $\alpha$-chains ( $\alpha 1$-chain and $\alpha 2$-chain) as a main constituent and a major $\beta$-chain. In addition, small amounts of the g component could also be observed in these samples $[84,106]$.

Scanning electron microscope (SEM) is also frequently described in studies regarding the extraction of collagen/ gelatin to investigate the collagen morphology, namely the presence and organization of fibrils [87, 107]. This technique could be used to evaluate the extent of the denaturation in collagen, the microstructure and surface area [100, 108]. The investigation of collagen and gelatin morphology provides a better understanding about possible applications of these products. For example, Zhang and colleagues [100] reported that ASC extracted from Nile tilapia and channel catfish skin possesses a complex fibril structure with high potential for cosmetic applications. Its ability to hold water is recommended for its application as hydrating agent. By its turn, PSC yielded a almost uniform multilayer morphology, which indicates higher compatibility with biomedical applications.

Apart from the above-mentioned methods of characterization, collagen and gelatin have also been studied for their functional properties including emulsifying, foaming, water and oil holding capacity $[95,96,108]$ as well as its mechanical and biological properties [91, 93, 106]. These important functional properties are very relevant in the food chemistry field. For example, the WHC and $\mathrm{OHC}$ are related to the texture by the interaction between gelatin and other components, such as water and oils.

\section{Hydroxyapatite}

Hydroxyapatite $\left[\mathrm{C}_{10}\left(\mathrm{PO}_{4}\right)_{6}(\mathrm{OH})_{2}, \mathrm{HAp}\right]$, as well as other calcium phosphate-based compounds, are employed as biomaterials, namely in the fabrication of bone implants and bone cements, due of their high biocompatibility [4, 109]. From a chemical and structural point of view, HAp with a $\mathrm{Ca} / \mathrm{P}$ molar ratio $=1.67$, is the most similar material to the inorganic part of bones and teeth [110].

Several methods for HAp synthesis, such as solid-state synthesis, chemical precipitation, hydrothermal treatment, radio frequency thermal plasma and polymer-assisted methods were described in literature [4, 111, 112]. However, these synthesis processes, are biologically hazardous, expensive and complex [110]. Extraction of HAp from byproducts of food industry (fish bones and scales) arises as a cheaper and uncomplicated alternative procedure [113, 114]. Also, the HAp obtained from natural sources, is more compatible than the synthetic counterpart.

\section{Extraction from Bones and Scales}

Before extraction of hydroxyapatite itself, soft tissues (such as cartilage and fragments of meat and skin) are removed manually from the bones using hot water $[10,110,111,115$, $116]$ The washed bones can be mixed with an alkaline solution and/or acetone to remove protein, lipids, oils and other organic impurities [117].

Isolation of HAp can be achieved by different methods, such as calcination, alkaline hydrolysis, enzymatic hydrolysis and ionic liquid pretreatment.

Calcination process is the most common way to produce HAp due to its low cost and simplicity. Different calcination temperature and duration of heat treatment result in HAp with different properties, namely in terms of the degree of crystallinity, crystallite size, and surface structure composition $[110,111,118]$. Lower calcination temperatures are recommended to produce medically preferable carbonated 
Table 5 Classification, advantages, and restrictions of the most common techniques used to characterize hydroxyapatite (adapted from [125])

\begin{tabular}{|c|c|c|}
\hline Technique & Advantages & Disadvantages \\
\hline FTIR & $\begin{array}{l}\text { Measurement over a narrow range of wavelengths at a time; } \\
\text { no external calibration is required; provides accurate and fast } \\
\text { results; identification of contaminants (even at small concen- } \\
\text { trations) }\end{array}$ & Inorganic materials are not easily analyzed by FTIR spectroscopy \\
\hline XRD & $\begin{array}{l}\text { Powerful and rapid technique; provides an unambiguous mineral } \\
\text { determination; data interpretation is relatively straightforward }\end{array}$ & $\begin{array}{l}\text { Homogeneous and single-phase materials are best for identifica- } \\
\text { tion of an unknown; peak overlay may occur, and it is worse for } \\
\text { high angle reflections }\end{array}$ \\
\hline EDS & $\begin{array}{l}\text { Provides unique peaks characteristic of the atomic structure of } \\
\text { the atoms; quick and versatile technique }\end{array}$ & Comparatively lower precision than SEM \\
\hline SEM & Direct visualization, high resolution & $\begin{array}{l}\text { Powder aggregation during the sample preparation; sometimes } \\
\text { needs TEM to confirm results }\end{array}$ \\
\hline TEM & Direct visualization, high resolution & $\begin{array}{l}\text { Powder aggregation during the sample preparation, electron beam } \\
\text { damage, preference for electron-dense atomic species }\end{array}$ \\
\hline
\end{tabular}

HAp, while higher temperatures $\left(800-1000^{\circ} \mathrm{C}\right)$ lead to elimination by heat of carbonated groups of HAp which affect its biological properties [110, 111, 117].

Alkaline hydrothermal hydrolysis is becoming popular nowadays. When applied, nanostructured carbonated HAp particles are produced, which are highly desirable for biomedical applications [117, 119].

All the above methods have associated environmental issues due to the use of acids and alkalis to separate the HAp from fish waste [120]. Huang et al. [112] successfully extracted HAp from tilapia scales by enzymatic hydrolysis (using protease $\mathrm{N}$ and flavourzyme). The extracted material showed low crystallinity and nanoparticle sizes with a $\mathrm{Ca} / \mathrm{P}$ molar ratio of 1.78. However the associated costs, as well as the time required and the need for controlled environment maintenance, make this process more complex.

Ionic liquid was recently presented as a novel approach for extraction of HAp from fish scales [121]. The extracted HAp showed a $\mathrm{Ca} / \mathrm{P}$ ratio of 1.60 , which is comparable with that of human bones. Ionic liquid interacts with collagen by hydrogen bond, dissolving it, while HAp remains undissolved and can be collected as a precipitate by centrifugation. Another advantage of this method is that the ionic liquid can be recycled.

\section{Characterization of Hydroxyapatite}

Various characterization techniques are used to characterize the HAp extracted from fish residue. The details about the advantages and limitations of the most common techniques are presented in Table 5.

Thermal gravimetric analysis (TGA) is often applied to study the thermal stability of the samples $[111,117$, 121-123]. Results of TGA analysis, performed on HAp from fish scales, showed one broad endothermic transitions peak in the differential thermal analysis DTA curve, at temperatures lower than $200{ }^{\circ} \mathrm{C}$, corresponding to the desorption of water. A small peak was detected at about $350{ }^{\circ} \mathrm{C}$, corresponding to the combustion of carbon compounds, indicating that the pretreatment was efficient in removing organic matter from the scales [122].

Functional groups at the surface of extracted HAp are characterized by FT-IR [110, 120, 121, 123, 124]. HAp shows various characteristic peaks in the FT-IR spectrum at $3572 \mathrm{~cm}^{-1}$ (OH stretching), 1087, 1046, $1032 \mathrm{~cm}^{-1}$ (P-O stretching) and 631, 602, and $574 \mathrm{~cm}^{-1}(\mathrm{O}-\mathrm{P}-\mathrm{O}$ bending) (Fig. 3a).

XRD provides extended information about the crystalline structure and is used to confirm the phase composition of HAp [112, 114, 116, 122, 124]. HAp shows a well resolved characteristic peak at 2-theta value of $32.2^{\circ}$ (211 plane of geometry) (Fig. 3b).

It is important to determine the amount of possible toxic elements since the HAp is obtained from biological sources [110]. For this, the chemical analysis of the extracted HAp is often performed by inductively coupled plasma atomic emission spectrometry [10, 110, 111, 122] or by flame atomic absorption spectroscopy [114].

Electron dispersive scanning analysis (EDS), used in combination with SEM, is a simpler approach to determine the elemental composition of HAp (in particular the $\mathrm{Ca} / \mathrm{P}$ molar ratio) (Fig. 3c) [112, 120]. However, it only allows a semi-quantitative analysis of the chemical elements.

Direct visualization using SEM and transmission electron microscopy (TEM) provides detailed information about the particle size, shape, morphology, dispersion and microstructure of HAp (Fig. 3d-e) [111, 114, 116, $123,125]$.

Because HAp plays an important role in the biomedical field, cytotoxicity and proliferation studies with different cell-lines are perfomed to confirm its biocompatibility [110, 112, 113, 117, 120, 123]. 

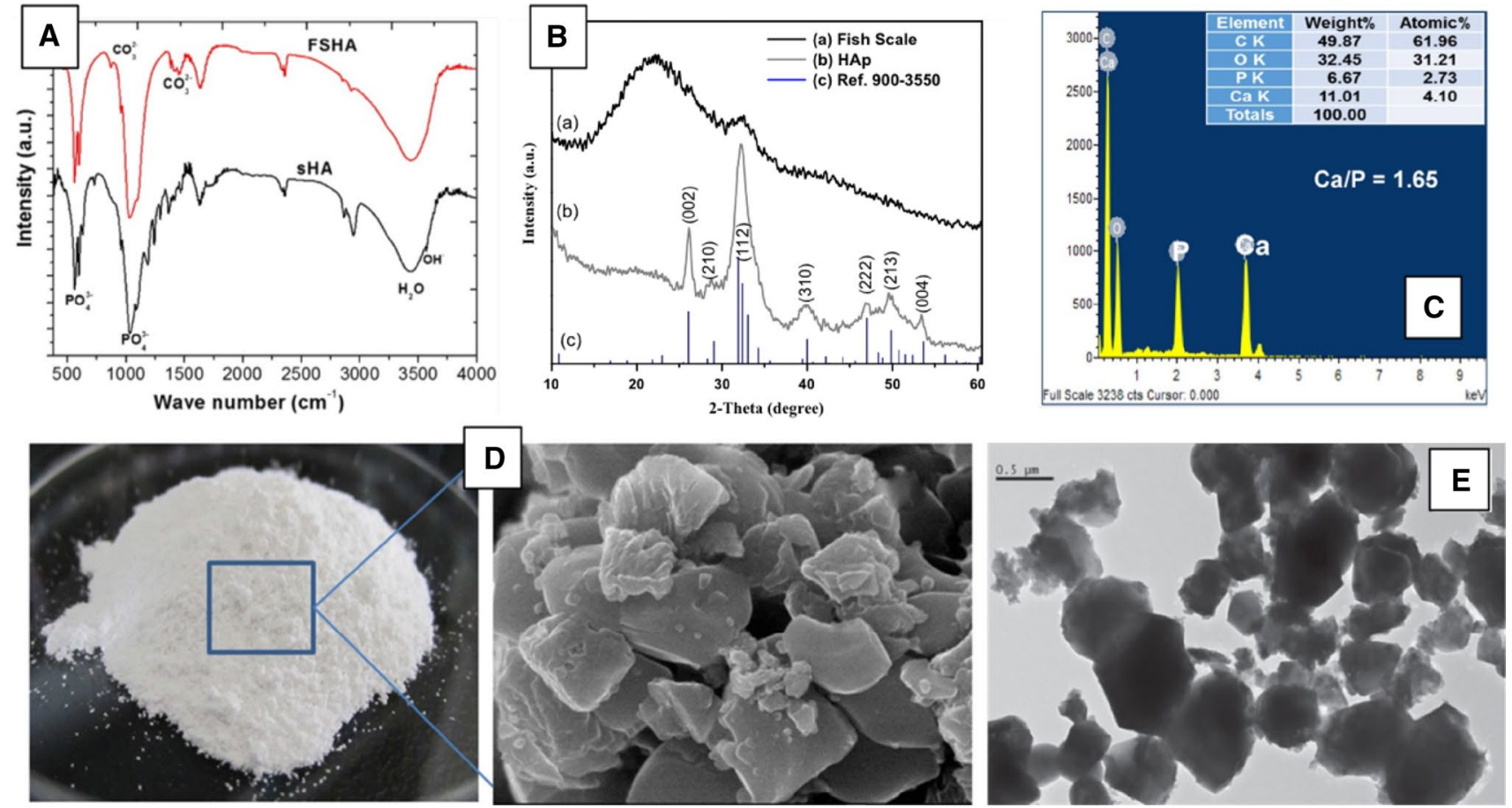

Fig. 3 Common techniques used to characterize Hap isolated from fish scales. HAp shows various characteristic peaks in the FT-IR spectrum (a) at $3438 \mathrm{~cm}^{-1}$ (OH stretching), 957, $1030 \mathrm{~cm}^{-1}$ (P-O stretching) and 563 and $602 \mathrm{~cm}^{-1}$ (O-P-O bending). The XRD profile of Hap (b) shows characteristic diffraction peaks at 26.1, 28.45, $32.90,40.19,46.82,50.05,53.56^{\circ}$, which correspond to the 002,210 ,

\section{Fish Oils}

Lipids from marine origin have a higher unsaturation degree compared with those of terrestrial organisms. That composition is usually determined by an acute identification and quantification of the fatty acids (FAs) content [69, 126]. Long chain polyunsaturated fatty acids (PUFAs) in the cis isomeric configuration such as eicosapentanoic acid (C20:5n3, EPA), arachidonic acid (C20:4n6, AA) and docosahexanoic acid (C22:6n3, DHA) are important precursors of prostaglandins, thromboxanes and leukotrienes [4, 127]. These essential FAs, being mostly obtained from the diet, are part of two related groups-omega 3 and omega 6 [128]. With growing awareness of the clinical benefits for this class of compounds, there is an increasing need to locate sources for human consumption. Accumulation of fatty acids in many lean fish species is predominantly in perivisceral organs (e.g. liver and intestine), with uptakes exceeding 50\% of the wet weight $[128,129]$.

\section{Lipid Extraction}

The research and characterization of FAs in fish oil requires prior extraction from raw material followed by
112, 310, 222, 213 and 004 planes of the hexagonal HAp unit cell. In EDS technique (c), the unique peaks of $\mathrm{Ca}, \mathrm{P}$, and $\mathrm{O}$ of HAp appear at their characteristic positions. SEM and TEM (d-e) provides direct information about the morphology, shape, size, and dispersion of Hap. Figures reproduced with permission from [112] (a), [120] (b-c), and [117] (d-e)

purification/separation $[4,130]$. Fishmeal process is the most common source of fish oil, since oil is generated as a by-product in the fishmeal industry. The extraction can be categorized into three categories: physical, chemical and biological. Physical extraction includes homogenizing, heating, pressing and filtering, also regarded as rendering. The bulk of fishmeal and oil is manufactured by the wet rendering method were direct steam is injected into the rendering tank, along with the material being rendered, as opposed to dry rendering, were steam is confined in a jacket that surrounds the tank containing the material [131]. Pressing is carried out to squeeze the oil from the slurry, which is followed by filtration or centrifugation to separate FAs from the miscela [126]. This is the most common and simple procedure to obtain fish oil at the industrial scale and allows the highest extraction yields. However, it is not so feasible when the oil content is low [127, 132].

Table 6 resumes the most common techniques used for lipid extraction. The first developed chemical methodology for the extraction of lipids was based in a liquid-liquid phase with a mixture of polar and non-polar solvents in specific ratios [127, 133]. This methodology serves as a benchmark for comparison between other solvent extraction methods. 


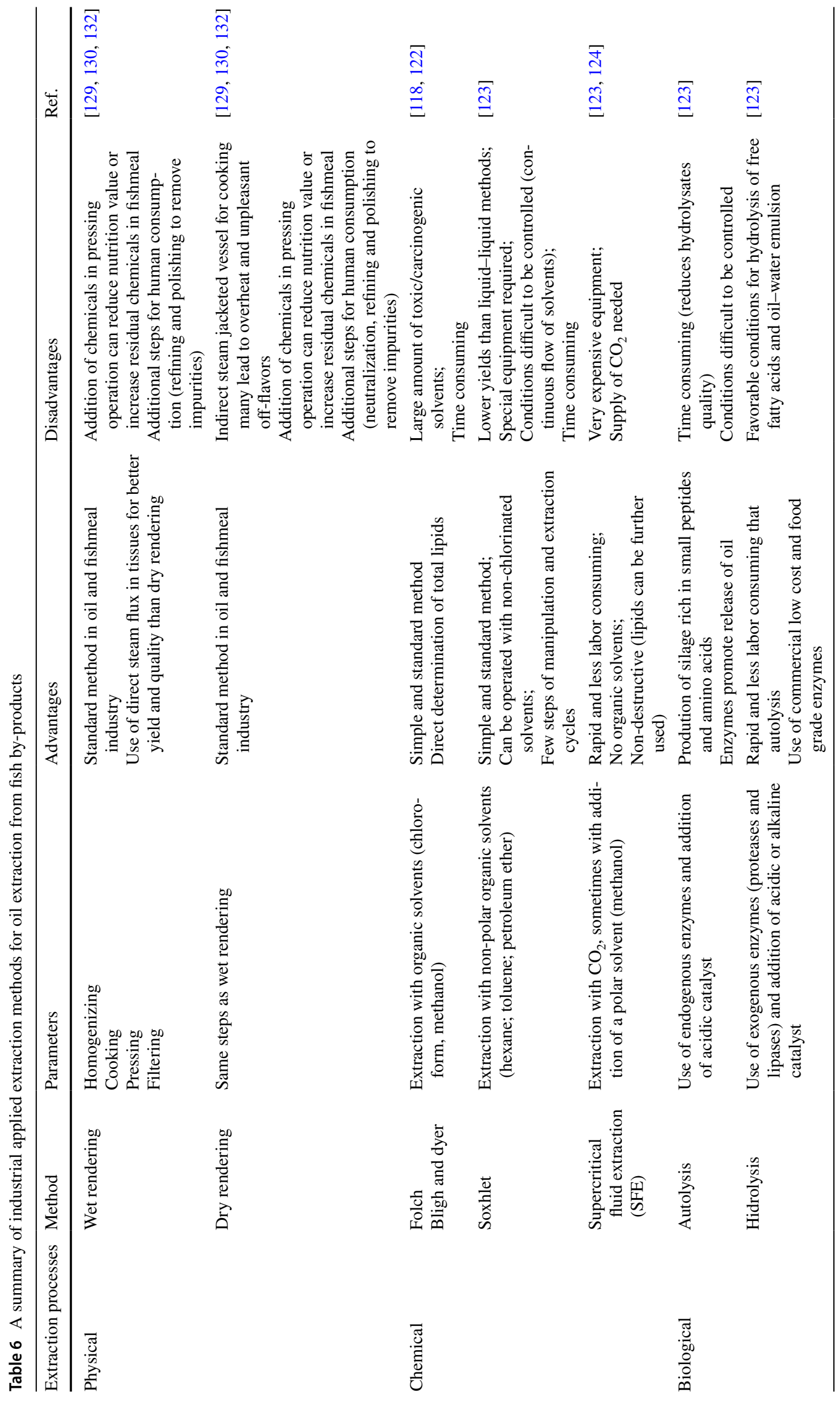


The Soxhlet extraction is based on solid-liquid extraction and excludes the need for filtration. However, its extraction efficiency is highly dependent on the properties of the organic solvent [126]. This methodology easily extracts triacylglycerols (TAGs) but the extraction of polar complex lipids like phospholipids is rather difficult, usually requiring a more polar co-solvent [126]. The system temperature required for evaporation and number of cycles must be considered, since it can influence lipid yield. Although solvent extraction is widely used for analytical purposes at the lab scale it has some drawbacks in the fish processing industry due to high energy costs, environmental concerns and restrictions of the use of solvents in the food industry.

The supercritical fluid extraction (SFE) is the most important breakthrough in lipid extraction, being considered as a potential replacement for the traditional organic solvent methodology [126, 134]. At supercritical conditions, fluids acquire special proprieties (gas-like low viscosity and high diffusivity and liquid-like high densities), enhancing the solvation and flow properties and making extraction faster and more effective [126, 127]. Supercritical $\mathrm{CO}_{2}$ is widely used as solvent, being considered a green solvent due to its low toxicity, cost and flammability [130, 135]. Additionally, using this technique fish oil can be fractionated into different components according to their molecular weight or degree of saturation. The major drawback for SFE- $\mathrm{CO}_{2}$ is related to the very expensive cost of the apparatus [126].

Biological methodologies include enzymatic oil extractions and silage production through the use of enzymes. These methods have become popular to recover fish oils since it can be simpler and cheaper regarding investment cost and energy expenses [127, 130].

Silage is the fish digest recovered using internal enzymes from viscera and acid for stability, in a process referred to autolysis. The process forms fish silage from muscle and aqueous solution rich in small peptides and aminoacids, and the enzymes promote the release of oil. If exogenous enzymes are used, the process is called hydrolysis. Addition of exogenous enzymes (lipases and proteases) sourced from either animal, vegetable or microbial, requires no organic solvents and makes hydrolysis highly controllable with reduced reaction time [136, 137]. Enzymatic reaction provides milder conditions in terms of temperature, which protects FAs from oxidation, isomerization, and other undesirable reactions, yielding better results than thermal procedures $[4,138]$. Another biological process for production of fish ensilage combines minced fish material with a carbohydrate source (sugar or molasses) or organic acids (lactic acid) and microorganism. The success of this fermentation is dependent of production of lactic acid by microorganism that must be sufficient to establish a pH below 4,5 [129].

Each technique has its own advantages and drawbacks and leads to different profiles of FAs concentrates. For example, SFE is suitable for the recovery of lipids as fatty acids esters, while acylglycerols can be obtained by enzymatic methods [4].

\section{Fatty Acids Characterization and Quantification}

To determine the FAs composition a three-step analysis is carried out, namely extraction, derivatization to their methyl ester forms and analysis.

One-dimensional thin Layer Chromatography (TLC) with silica gel has been used for lipid class separation for many years, mainly for inexpensive and flexible requirements $[139,140]$. Commonly, the solvent elution system consists in a mixture of polar/non-polar solvents. One of the drawbacks in TLC characterization is co-elution of some classes with similar polarity, requiring a previous small-scale procedure of isolation based on a column of silica gel with polar/nonpolar solvents.

Some methods of analysis of fatty acids as their methyl esters rely on a previous saponification of lipids before converting into FAMEs. This method consists on heating the extracts under reflux with an excess of dilute aqueous ethanolic alkaline solution. The saponifiable layer contains the FAs and the non-polar hydrocarbons, long chain alcohols, sterol and glycerol ether are separated in the non-saponifiable layer [140].

The esterification of FAs to FAMEs, to improve their volatility, is performed by derivatization using an alkylation reagent, before gas-chromatography (GC) analysis. There are many esterification methods described in literature, each varying the derivatization reagent since no single reagent will suffice, giving a choice for the analyst to best fit the circumstances. The commonest reagent for the preparation of FAMEs is $\mathrm{HCl}$ in methanol. A solution of concentrated sulfuric acid in methanol used for esterification is recommended [141]. A comparison of different derivatization reagents and mechanisms is well presented in the Ref. [140]. The former methodology is nowadays being neglected for in situ transesterification, that allows a faster processing of samples. In situ transesterification refers to the direct transesterification of lipids in a matrix without prior lipid extraction and saponification. This procedure is gaining recognition as a lipid measurement process [134, 142] and can be carried out using both acid and base derivatization reagent, or a combination of both [143, 144].

GC is the preferred technique in characterization and quantification of FAMEs. The flame ionization detector (FID) is universally used in fatty acid quantification, with high sensitivity and stability, low dead volume and fast and linear response time linear over a wide range [140]. Mass spectrometry (MS) coupled with a GC gives detailed spectrometric information of FAMEs, offering two important advantages over FID: the ability to confirm the identity of 
analytes based on spectral information, and separation of peaks from a noisy background or coeluting peaks if unique ions are available [145].

Nuclear magnetic resonance (NMR) spectroscopy analysis of commercial fish oil has been used to provide discrimination concerning the nature, composition, refinement, and/ or adulteration or authentication of products [146]. Furthermore, NMR provides a complementary analysis for characterization and quantification of FAMEs by GC-FID. Other advantages of NMR include simple sample preparation and short analysis time. However, the cost of the equipment is the most prohibitive limitation of its use.

\section{Conclusions}

Every year, worldwide, FPI is responsible for the production of high amounts of biowaste. Despite some of these residues are already used, a more sustainable exploitation of these natural resources is an asset. Fish by-products, such as bones, scales, skin and viscera have been studied as potential raw materials for isolation of added-value compounds, with different applications on several fields. Although several processes are already described in the literature, it is possible to isolate different compounds from the same byproduct. Both collagens and hydroxyapatites can be obtained from scales/bones, corresponding to an integral valorization of these morphological parts, heretofore regarded as waste. Essential FAs can be isolated from viscera, as well as proteolytic enzymes for several industrial purposes. These enzymes can be also applied in enzymatic hydrolysis processes for processing other morphological parts, operating in a loop (e.g. isolation of hydroxyapatite from the scales using endogenous enzymatic hydrolysis).

Because some of the processes are industrially achievable, research regarding the valorization of the FPI by-products may result in the generation of economically attractive products. More importantly, this will result in a significant reduction of wastes, giving rise to a more beneficial alternative to the disposal methods currently employed.

This review is focused on the techniques for extraction and characterization of added-value materials from FPI waste. Methods and techniques developed for the extraction and characterization of materials from other sources can be easily adjusted to take in consideration the specific features of fish by-products. Industrial processes are feasible, thus simultaneously permitting the reduction of waste and the obtainment of added-value materials.

Acknowledgements This work was supported by FCT-Fundação para a Ciência e a Tecnologia (projectPEst-OE/QUI/UI0674/2019, CQM, Portuguese Government funds), and through Madeira 14-20 Program, project PROEQUIPRAM - Reforço do Investimento em Equipamentos e Infraestruturas Científicas na RAM (M1420-01-0145-FEDER-000008) and by ARDITI-Agência Regional para o Desenvolvimento da Investigação Tecnologia e Inovação, through the project M1420-01-0145FEDER-000005-Centro de Química da Madeira- $\mathrm{CQM}^{+}$(Madeira 14-20). The work was also performed in the frame of project MarineBlueRefine PROCiência2020 (Portaria n ${ }^{\circ} 371 / 2015$, de 16/12), M142001-0247-FEDER-000006; Pedro Ideia is the recipient of a PhD Grant under the project M1420-09-5369-FSE-000001.

\section{Compliance with Ethical Standards}

Conflicts of interest The author declares no conflict of interest.

\section{References}

1. FAO: The State of World Fisheries and Aquaculture-Opportunities and Challenges. FAO, Rome (2014)

2. Chalamaiah, M., Dinesh Kumar, B., Hemalatha, R., Jyothirmayi, T.: Fish protein hydrolysates: proximate composition, amino acid composition, antioxidant activities and applications: a review. Food Chem. 135, 3020-3038 (2012). https://doi.org/10.1016/j. foodchem.2012.06.100

3. Caruso, G.: Fishery wastes and by-products: a resource to be valorised. J. Fish. Sci. 9, 080-083 (2015)

4. Ferraro, V., Cruz, I.B., Jorge, R.F., Malcata, F.X., Pintado, M.E., Castro, P.M.L.: Valorisation of natural extracts from marine source focused on marine by-products: a review. Food Res. Int. 43, 2221-2233 (2010). https://doi.org/10.1016/j.foodr es.2010.07.034

5. Hsu, K.-C.: Purification of antioxidative peptides prepared from enzymatic hydrolysates of tuna dark muscle by-product. Food Chem. 122, 42-48 (2010). https://doi.org/10.1016/J.FOODC HEM.2010.02.013

6. Schmidt, Dornelles, R.C.P., Mello, R.O., Kubota, E.H., Mazutti, M.A., Kempka, Demiate, I.M.: Collagen extraction process. Int. Food Res. J. 23, 913-922 (2016)

7. Liceaga-Gesualdo, A., Li-Chan, E.C.: Functional properties of fish protein hydrolysate from herring (Clupea harengus). J. Food Sci. 64, 1000-1004 (1999)

8. Chantachum, S., Benjakul, S., Sriwirat, N.: Separation and quality of fish oil from precooked and non-precooked tuna heads. Food Chem. 69, 289-294 (2000). https://doi.org/10.1016/S0308 $-8146(99) 00266-6$

9. Montero, P., Gomez-Guillen, M.C.: Extracting conditions for megrim (Lepidorhombus boscii) skin collagen affect functional properties of the resulting gelatin. J. Food Sci. 65, 434-438 (2000). https://doi.org/10.1111/j.1365-2621.2000.tb16022.x

10. Ozawa, M., Suzuki, S.: Microstructural development of natural hydroxyapatite originated from fish-bone waste through heat treatment. J. Argent. Chem. Soc. 17, 2000-2002 (2002). https:// doi.org/10.1111/j.1151-2916.2002.tb00268.x

11. Kim, S.-K., Park, P.-J., Kim, J.-B., Shahidi, F.: Purification and characterization of a collagenolytic protease from the filefish, Novoden modestrus. J. Biochem. Mol. Biol. 35, 165-171 (2002)

12. Kim, S.K., Mendis, E.: Bioactive compounds from marine processing byproducts-a review. Food Res. Int. 39, 383-393 (2006). https://doi.org/10.1016/j.foodres.2005.10.010

13. Gildberg, A.: Enzymes and bioactive peptides from fish waste related to fish silage, fish Feed and fish Sauce production. J. Aquat. Food Prod. Technol. 13, 3-11 (2004). https://doi. org/10.1300/J030v13n02

14. Gildberg, A., Simpson, B.K., Haard, N.F.: Uses of enzymes from marine organisms. In: Haard, N.F., Simpson, B.K. (eds.) Seafood 
Enzymes: Utilization and Influence on Postharvest Seafood Quality, pp. 619-639. Marcel Dekker Inc, New York (2000)

15. Gildberg, A.: Digestive enzyme activities in starved pre-slaughter farmed and wild-captured, Atlantic cod (Gadus morhua). Aquaculture 238, 343-353 (2004). https://doi.org/10.1016/j.aquacultur e.2004.03.021

16. Zhao, L., Budge, S.M., Ghaly, A.E., Brooks, S.M.: Extraction, purification and characterization of fish pepsin: a critical review. J. Food Process. Technol. (2011). https://doi.org/10.4172/21577110.1000126

17. Fernandes, P.: Enzymes in fish and seafood processing. Front. Bioeng. Biotechnol. 4, 1-14 (2016). https://doi.org/10.3389/fbioe 2016.00059

18. Shahidi, F., Janak Kamil, Y.V.A.: Enzymes from fish and aquatic invertebrates and their application in the food industry. Trends Food Sci. Technol. 12, 435-464 (2001). https://doi.org/10.1016/ s0924-2244(02)00021-3

19. Souza, A.A.G., Amaral, I.P.G., Santo, A.R.E., Carvalho, L.B., Bezerra, R.S.: Trypsin-like enzyme from intestine and pyloric caeca of spotted goatfish (Pseudupeneus maculatus). Food Chem. 100, 1429-1434 (2007). https://doi.org/10.1016/j.foodc hem.2005.12.016

20. Silva, J.F., Espósito, T.S., Marcuschi, M., Ribeiro, K., Cavalli, R.O., Oliveira, V., Bezerra, R.S.: Purification and partial characterisation of a trypsin from the processing waste of the silver mojarra (Diapterus rhombeus). Food Chem. 129, 777-782 (2011). https://doi.org/10.1016/j.foodchem.2011.05.019

21. Bougatef, A., Souissi, N., Fakhfakh, N., Ellouz-Triki, Y., Nasri, M.: Purification and characterization of trypsin from the viscera of sardine (Sardina pilchardus). Food Chem. 102, 343-350 (2007). https://doi.org/10.1016/j.foodchem.2006.05.050

22. Marcuschi, M., Espósito, T.S., Machado, M.F.M., Hirata, I.Y., Machado, M.F.M., Silva, M.V., Carvalho, L.B., Oliveira, V., Bezerra, R.S.: Purification, characterization and substrate specificity of a trypsin from the Amazonian fish tambaqui (Colossoma macropomum). Biochem. Biophys. Res. Commun. 396, 667-673 (2010). https://doi.org/10.1016/j.bbrc.2010.04.155

23. Khantaphant, S., Benjakul, S.: Purification and characterization of trypsin from the pyloric caeca of brownstripe red snapper (Lutjanus vitta). Food Chem. 120, 658-664 (2010). https://doi. org/10.1016/j.foodchem.2009.09.098

24. Fuchise, T., Kishimura, H., Sekizaki, H., Nonami, Y., Kanno, G., Klomklao, S., Benjakul, S., Chun, B.S.: Purification and characteristics of trypsins from cold-zone fish, Pacific cod (Gadus macrocephalus) and saffron cod (Eleginus gracilis). Food Chem. 116, 611-616 (2009). https://doi.org/10.1016/j.foodchem.2009.02.078

25. Lu, B.J., Zhou, L.G., Cai, Q.F., Hara, K., Maeda, A., Su, W.J., Cao, M.J.: Purification and characterisation of trypsins from the pyloric caeca of mandarin fish (Siniperca chuatsi). Food Chem. 110, 352-360 (2008). https://doi.org/10.1016/j.foodc hem.2008.02.010

26. Nalinanon, S., Benjakul, S., Visessanguan, W., Kishimura, H.: Partitioning of protease from stomach of albacore tuna (Thunnus alalunga) by aqueous two-phase systems. Process Biochem. 44, 471-476 (2009). https://doi.org/10.1016/j.procbio.2008.12.018

27. Spelzini, D., Farruggia, B., Picó, G.: Features of the acid protease partition in aqueous two-phase systems of polyethylene glycolphosphate: chymosin and pepsin. J. Chromatogr. B 821, 60-66 (2005). https://doi.org/10.1016/J.JCHROMB.2005.04.007

28. Tubío, G., Nerli, B., Picó, G.: Partitioning features of bovine trypsin and $\alpha$-chymotrypsin in polyethyleneglycol-sodium citrate aqueous two-phase systems. J. Chromatogr. B 852, 244-249 (2007). https://doi.org/10.1016/J.JCHROMB.2007.01.025

29. Merz, M., Claaßen, W., Appel, D., Berends, P., Rabe, S., Blank, I., Stressler, T., Fischer, L.: Characterization of commercially available peptidases in respect of the production of protein hydrolysates with defined compositions using a three-step methodology. J. Mol. Catal. B Enzym. 127, 1-10 (2016)

30. Cao, M.J., Chen, W.Q., Du, C.H., Yoshida, A., Lan, W.G., Liu, G.M., Su, W.J.: Pepsinogens and pepsins from Japanese seabass (Lateolabrax japonicus). Comp. Biochem. Physiol. B: Biochem. Mol. Biol. 158, 259-265 (2011). https://doi.org/10.1016/j. cbpb.2010.12.003

31. Klomklao, S., Kishimura, H., Yabe, M., Benjakul, S.: Purification and characterization of two pepsins from the stomach of pectoral rattail (Coryphaenoides pectoralis). Comp. Biochem. Physiol. B: Biochem. Mol. Biol. 147, 682-689 (2007). https:// doi.org/10.1016/j.cbpb.2007.04.008

32. Nalinanon, S., Benjakul, S., Kishimura, H.: Biochemical properties of pepsinogen and pepsin from the stomach of albacore tuna (Thunnus alalunga). Food Chem. 121, 49-55 (2010). https://doi. org/10.1016/J.FOODCHEM.2009.11.089

33. Tanji, M., Yakabe, E., Kageyama, T., Yokobori, S.I., Ichinose, M., Miki, K., Ito, H., Takahashi, K.: Purification and characterization of pepsinogens from the gastric mucosa of African coelacanth, Latimeria chalumnae, and properties of the major pepsins. Comp. Biochem. Physiol. B: Biochem. Mol. Biol. 146, 412-420 (2007). https://doi.org/10.1016/j.cbpb.2006.11.025

34. Wu, T., Sun, L.C., Du, C.H., Cai, Q.F., Zhang, Q.B., Su, W.J., Cao, M.J.: Identification of pepsinogens and pepsins from the stomach of European eel (Anguilla anguilla). Food Chem. 115, 137-142 (2009). https://doi.org/10.1016/j.foodchem.2008.11.077

35. Zhou, Q., Liu, G.M., Huang, Y.Y., Weng, L., Hara, K., Su, W.J., Cao, M.J.: Pepsinogens and pepsins from mandarin fish (Siniperca chuatsi). J. Agric. Food Chem. 56, 5401-5406 (2008). https://doi.org/10.1021/jf800458n

36. Candiotto, F.B., Freitas-Júnior, A.C.V., Neri, R.C.A., Bezerra, R.S., Rodrigues, R.V., Sampaio, L.A., Tesser, M.B.: Characterization of digestive enzymes from captive Brazilian flounder Paralichthys orbignyanus. Braz. J. Biol. 78, 281-288 (2017)

37. Kishimura, H., Klomklao, S., Benjakul, S., Chun, B.S.: Characteristics of trypsin from the pyloric ceca of walleye pollock (Theragra chalcogramma). Food Chem. 106, 194-199 (2008). https://doi.org/10.1016/j.foodchem.2007.05.056

38. Klomklao, S., Kishimura, H., Nonami, Y., Benjakul, S.: Biochemical properties of two isoforms of trypsin purified from the Intestine of skipjack tuna (Katsuwonus pelamis). Food Chem. 115, 155-162 (2009). https://doi.org/10.1016/j.foodc hem.2008.11.087

39. Gildberg, A.: Utilisation of male Arctic capelin and Atlantic cod intestines for fish sauce production - evaluation of fermentation conditions. Bioresour. Technol. 76, 119-123 (2001). https://doi. org/10.1016/S0960-8524(00)00095-X

40. Bougatef, A., Balti, R., Zaied, S.B., Souissi, N., Nasri, M.: Pepsinogen and pepsin from the stomach of smooth hound (Mustelus mustelus): purification, characterization and amino acid terminal sequences. Food Chem. 107, 777-784 (2008). https://doi. org/10.1016/j.foodchem.2007.08.077

41. El-Beltagy, A., El-Adawy, T., Rahma, E., El-Bedawey, A.: Purification and characterization of an acidic protease from the viscera of bolti fish (Tilapia nilotica). Food Chem. 86, 33-39 (2004). https://doi.org/10.1016/J.FOODCHEM.2003.08.009

42. Castillo-Yañez, F.J., Pacheco-Aguilar, R., Garcia-Carreño, F.L., Navarrete-Del Toro, M.D.L.A.: Characterization of acidic proteolytic enzymes from Monterey sardine (Sardinops sagax caerulea) viscera. Food Chem. 85, 343-350 (2004). https://doi. org/10.1016/j.foodchem.2003.07.008

43. Castillo-Yáñez, F.J., Pacheco-Aguilar, R., García-Carreño, F.L., Navarrete-Del Toro, M.D.L.Á.: Isolation and characterization of trypsin from pyloric caeca of Monterey sardine Sardinops sagax caerulea. Comp. Biochem. Physiol. B: Biochem. Mol. Biol. 140, 91-98 (2005). https://doi.org/10.1016/j.cbpc.2004.09.031 
44. Wu, R., Wu, C., Liu, D., Yang, X., Huang, J., Zhang, J., Liao, B., $\mathrm{He}, \mathrm{H}$., Li, H.: Overview of antioxidant peptides derived from marine resources: the sources, characteristic, purification, and evaluation methods. Appl. Biochem. Biotechnol. 176, 1815-1833 (2015). https://doi.org/10.1007/s12010-015-1689-9

45. Guérard, F., Dufossé, L., De La Broise, D., Binet, A.: Enzymatic hydrolysis of proteins from yellowfin tuna (Thunnus albacares) wastes using Alcalase. J. Mol. Catal. B Enzym. 11, 1051-1059 (2001). https://doi.org/10.1016/S1381-1177(00)00031-X

46. Šližytè, R., Daukšas, E., Falch, E., Storrø, I., Rustad, T.: Characteristics of protein fractions generated from hydrolysed cod (Gadus morhua) by-products. Process Biochem. 40, 2021-2033 (2005). https://doi.org/10.1016/j.procbio.2004.07.016

47. Vázquez, J., Blanco, M., Massa, A., Amado, I., Pérez-Martín, R.: Production of fish protein hydrolysates from Scyliorhinus canicula discards with antihypertensive and antioxidant activities by enzymatic hydrolysis and mathematical optimization using response surface methodology. Mar. Drugs 15, 306 (2017). https ://doi.org/10.3390/md15100306

48. Himonides, A.T., Taylor, A.K.D., Morris, A.J.: A study of the enzymatic hydrolysis of fish frames using model systems. Food Nutr. Sci. 2, 575-585 (2011). https://doi.org/10.4236/ fns.2011.26081

49. Bhaskar, N., Benila, T., Radha, C., Lalitha, R.G.: Optimization of enzymatic hydrolysis of visceral waste proteins of Catla (Catla catla) for preparing protein hydrolysate using a commercial protease. Bioresour. Technol. 99, 335-343 (2008). https://doi. org/10.1016/j.biortech.2006.12.015

50. Wang, W., Li, Z., Liu, J., Wang, Y., Liu, S., Sun, M.: Comparison between thermal hydrolysis and enzymatic proteolysis processes for the preparation of tilapia skin. Czech J. Food Sci. 31, 1-4 (2013)

51. Murthy, P.S., Rai, A.K., Bhaskar, N.: Fermentative recovery of lipids and proteins from freshwater fish head waste with reference to antimicrobial and antioxidant properties of protein hydrolysate. J. Food Sci. Technol. 51, 1884-1892 (2014). https://doi. org/10.1007/s13197-012-0730-Z

52. Villamil, O., Váquiro, H., Solanilla, J.F.: Fish viscera protein hydrolysates: production, potential applications and functional and bioactive properties. Food Chem. 224, 160-171 (2017). https ://doi.org/10.1016/j.foodchem.2016.12.057

53. Najafian, L., Babji, A.S.S.: A review of fish-derived antioxidant and antimicrobial peptides: their production, assessment, and applications. Peptides 33, 178-185 (2012). https://doi. org/10.1016/j.peptides.2011.11.013

54. Wang, X., Yu, H., Xing, R., Li, P.: Characterization, preparation, and purification of marine bioactive peptides. Biomed. Res. Int. 2017, 1-16 (2017). https://doi.org/10.1155/2017/9746720

55. Ishak, N.H., Sarbon, N.M.: A review of protein hydrolysates and bioactive peptides deriving from wastes generated by fish processing. Food Bioprocess Technol. 11, 2-16 (2018). https://doi. org/10.1007/s11947-017-1940-1

56. Klompong, V., Benjakul, S., Kantachote, D., Shahidi, F.: Antioxidative activity and functional properties of protein hydrolysate of yellow stripe trevally (Selaroides leptolepis) as influenced by the degree of hydrolysis and enzyme type. Food Chem. 102, 1317-1327 (2007). https://doi.org/10.1016/J.FOODC HEM.2006.07.016

57. Elavarasan, K., Naveen Kumar, V., Shamasundar, B.A.: Antioxidant and functional properties of fish protein hydrolysates from fresh water Carp (Catla catla) as influenced by the nature of enzyme. J. Food Process. Preserv. 38, 1207-1214 (2014). https ://doi.org/10.1111/jfpp.12081

58. Ben Khaled, H., Ktari, N., Ghorbel-Bellaaj, O., Jridi, M., Lassoued, I., Nasri, M.: Composition, functional properties and in vitro antioxidant activity of protein hydrolysates prepared from sardinelle (Sardinella aurita) muscle. J. Food Sci. Technol. 51, 622-633 (2014). https://doi.org/10.1007/s13197-011-0544-4

59. Jamil, N.H., Halim, N.R.A., Sarbon, N.M.: Optimization of enzymatic hydrolysis condition and functional properties of eel (Monopterus sp.) protein using response surface methodology (RSM). Int. Food Res. J. 23, 1-9 (2016)

60. Jemil, I., Jridi, M., Nasri, R., Ktari, N., Salem, R.B.S.-B., Mehiri, M., Hajji, M., Nasri, M.: Functional, antioxidant and antibacterial properties of protein hydrolysates prepared from fish meat fermented by Bacillus subtilis A26. Process Biochem. 49, 963972 (2014). https://doi.org/10.1016/j.procbio.2014.03.004

61. Ktari, N., Jridi, M., Bkhairia, I., Sayari, N., Ben Salah, R., Nasri, M.: Functionalities and antioxidant properties of protein hydrolysates from muscle of zebra blenny (Salaria basilisca) obtained with different crude protease extracts. Food Res. Int. 49, 747-756 (2012). https://doi.org/10.1016/J.FOODRES.2012.09.024

62. Liu, Y., Li, X., Chen, Z., Yu, J., Wang, F., Wang, J.: Characterization of structural and functional properties of fish protein hydrolysates from surimi processing by-products. Food Chem. 151, 459-465 (2014). https://doi.org/10.1016/J.FOODC HEM.2013.11.089

63. Taheri, A., Anvar, S.A.A., Ahari, H., Fogliano, V.: Comparison the functional properties of protein hydrolysates from poultry byproducts and rainbow trout. Iran. J. Fish. Sci. 12, 154-169 (2013)

64. Tanuja, S., Viji, P., Zynudheen, A., Joshy, C.: Composition, functional properties and antioxidative activity of hydrolysates prepared from the frame meat of Striped catfish (Pangasianodon hypophthalmus). Egypt. J. Biol. 14, 27-35 (2012). https://doi. org/10.4314/ejb.v14i1.3

65. Batista, I., Pires, C.: Utilization of Fish Waste Chapter 3: Functional Properties of Fish Protein Hydrolysates, pp. 59-75. CRC Press, Boca Raton (2013)

66. Kristinsson, H.G., Rasco, B.A.: Fish protein hydrolysates: production, biochemical, and functional properties. Crit. Rev. Food Sci. Nutr. 40, 43-81 (2000). https://doi.org/10.1080/1040869009 1189266

67. Zayas, J.F.: Functionality of Proteins in Food Chapter 4: Oil and Fat Binding Properties of Proteins, pp. 228-259. Springer, Berlin (1997)

68. Kaur, M., Singh, N.: Characterization of protein isolates from different Indian chickpea (Cicer arietinum L.) cultivars. Food Chem. 102, 366-374 (2007). https://doi.org/10.1016/j.foodc hem.2006.05.029

69. Halim, N.R.A.R.A., Yusof, H.M.M., Sarbon, N.M.M.: Functional and bioactive properties of fish protein hydolysates and peptides: a comprehensive review. Trends Food Sci. Technol. 51, 24-33 (2016). https://doi.org/10.1016/j.tifs.2016.02.007

70. Cheng, X., Tang, X., Wang, Q., Mao, X.Y.: Antibacterial effect and hydrophobicity of yak $\kappa$-casein hydrolysate and its fractions. Int. Dairy J. 31, 111-116 (2013). https://doi.org/10.1016/J.IDAIR YJ.2012.12.004

71. Venkatesan, J., Anil, S., Kim, S.-K., Shim, M.: Marine fish proteins and peptides for cosmeceuticals: a review. Mar. Drugs 15, 143 (2017). https://doi.org/10.3390/md15050143

72. Silva, T.H., Moreira-Silva, J., Marques, A.L.P., Domingues, A., Bayon, Y., Reis, R.L.: Marine origin collagens and its potential applications. Mar. Drugs 12, 5881-5901 (2014). https://doi. org/10.3390/md12125881

73. Gómez-Guillén, M.C., Giménez, B., López-Caballero, M.E., Montero, M.P.: Functional and bioactive properties of collagen and gelatin from alternative sources: a review. Food Hydrocoll. 25, 1813-1827 (2011). https://doi.org/10.1016/j.foodh yd.2011.02.007

74. Karim, A.A., Bhat, R.: Fish gelatin: properties, challenges, and prospects as an alternative to mammalian gelatins. Food 
Hydrocoll. 23, 563-576 (2009). https://doi.org/10.1016/J. FOODHYD.2008.07.002

75. Karayannakidis, P.D., Zotos, A.: Fish processing by-products as a potential source of gelatin: a review. J. Aquat. Food Prod. Technol. 25, 65-92 (2016). https://doi.org/10.1080/10498 850.2013.827767

76. Alfaro, A.T., Biluca, F.C., Marquetti, C., Tonial, I.B., de Souza, N.E.: African catfish (Clarias gariepinus) skin gelatin: extraction optimization and physical-chemical properties. Food Res. Int. 65, 416-422 (2014). https://doi.org/10.1016/J.FOODR ES.2014.05.070

77. Chen, J., Li, L., Yi, R., Xu, N., Gao, R., Hong, B.: Extraction and characterization of acid-soluble collagen from scales and skin of tilapia (Oreochromis niloticus). LWT-Food Sci. Technol. 66, 453-459 (2016). https://doi.org/10.1016/j. lwt.2015.10.070

78. Chuaychan, S., Benjakul, S., Kishimura, H.: Characteristics of acid- and pepsin-soluble collagens from scale of seabass (Lates calcarifer). LWT Food Sci. Technol. 63, 71-76 (2015). https ://doi.org/10.1016/J.LWT.2015.03.002

79. Kaewdang, O., Benjakul, S., Kaewmanee, T., Kishimura, H.: Characteristics of collagens from the swim bladders of yellowfin tuna (Thunnus albacares). Food Chem. 155, 264-270 (2014). https://doi.org/10.1016/j.foodchem.2014.01.076

80. Liu, D., Liang, L., Regenstein, J.M., Zhou, P.: Extraction and characterisation of pepsin-solubilised collagen from fins, scales, skins, bones and swim bladders of bighead carp (Hypophthalmichthys nobilis). Food Chem. 133, 1441-1448 (2012). https://doi.org/10.1016/J.FOODCHEM.2012.02.032

81. Mahboob, S.: Isolation and characterization of collagen from fish waste material- skin, scales and fins of Catla catla and Cirrhinus mrigala. J. Food Sci. Technol. (2014). https://doi. org/10.1007/s13197-014-1520-6

82. Ramanathan, G., Muthukumar, T., Tirichurapalli Sivagnanam, U.: In vivo efficiency of the collagen coated nanofibrous scaffold and their effect on growth factors and pro-inflammatory cytokines in wound healing. Eur. J. Pharmacol. 814, 45-55 (2017). https://doi.org/10.1016/J.EJPHAR.2017.08.003

83. Li, Q., Mu, L., Zhang, F., Sun, Y., Chen, Q., Xie, C., Wang, H.: A novel fish collagen scaffold as dural substitute. Mater. Sci. Eng., C 80, 346-351 (2017). https://doi.org/10.1016/J. MSEC.2017.05.102

84. Bhagwat, P.K., Dandge, P.B.: Isolation, characterization and valorizable applications of fish scale collagen in food and agriculture industries. Biocatal. Agric. Biotechnol. 7, 234-240 (2016). https://doi.org/10.1016/J.BCAB.2016.06.010

85. Ahmad, T., Ismail, A., Ahmad, S.A., Khalil, K.A., Kumar, Y., Adeyemi, K.D., Sazili, A.Q.: Recent advances on the role of process variables affecting gelatin yield and characteristics with special reference to enzymatic extraction: a review. Food Hydrocoll. 63, 85-96 (2017). https://doi.org/10.1016/J. FOODHYD.2016.08.007

86. Pal, G.K., Suresh, P.V.: Comparative assessment of physicochemical characteristics and fibril formation capacity of thermostable carp scales collagen. Mater. Sci. Eng., C 70, 32-40 (2017). https://doi.org/10.1016/j.msec.2016.08.047

87. Wang, J.K., Yeo, K.P., Chun, Y.Y., Tan, T.T.Y., Tan, N.S., Angeli, V., Choong, C.: Fish scale-derived collagen patch promotes growth of blood and lymphatic vessels in vivo. Acta Biomater. 63, 246-260 (2017). https://doi.org/10.1016/J. ACTBIO.2017.09.001

88. Gildberg, A., Arnesen, J.A., Carlehög, M.: Utilisation of cod backbone by biochemical fractionation. Process Biochem. 38, 475-480 (2002). https://doi.org/10.1016/S0032 $-9592(02) 00103-6$
89. Regenstein, J.M., Zhou, P.: Collagen and gelatin from marine by-products. Maximising Value Mar. By-Prod. (2007). https:// doi.org/10.1533/9781845692087.2.279

90. Sinthusamran, S., Benjakul, S., Kishimura, H.: Comparative study on molecular characteristics of acid soluble collagens from skin and swim bladder of seabass (Lates calcarifer). Food Chem. 138, 2435-2441 (2013). https://doi.org/10.1016/j.foodc hem.2012.11.136

91. Coelho, R.C.G., Marques, A.L.P., Oliveira, S.M., Diogo, G.S., Pirraco, R.P., Moreira-Silva, J., Xavier, J.C., Reis, R.L., Silva, T.H., Mano, J.F.: Extraction and characterization of collagen from Antarctic and Sub-Antarctic squid and its potential application in hybrid scaffolds for tissue engineering. Mater. Sci. Eng., C 78, 787-795 (2017). https://doi.org/10.1016/j.msec.2017.04.122

92. Ali, A.M.M., Kishimura, H., Benjakul, S.: Extraction efficiency and characteristics of acid and pepsin soluble collagens from the skin of golden carp (Probarbus Jullieni) as affected by ultrasonication. Process Biochem. 66, 237-244 (2018). https://doi. org/10.1016/J.PROCBIO.2018.01.003

93. Muhammed, A., Ali, M., Kishimura, H., Benjakul, S.: Physicochemical and molecular properties of gelatin from skin of golden carp (Probarbus Jullieni) as influenced by acid pretreatment and prior-ultrasonication. Food Hydrocoll. (2018). https:// doi.org/10.1016/j.foodhyd.2018.03.052

94. Khong, N.M.H., Yusoff, F.M., Jamilah, B., Basri, M., Maznah, I., Chan, K.W., Armania, N., Nishikawa, J.: Improved collagen extraction from jellyfish (Acromitus hardenbergi) with increased physical-induced solubilization processes. Food Chem. 251, 41-50 (2018). https://doi.org/10.1016/J.FOODC HEM.2017.12.083

95. Sila, A., Martinez-Alvarez, O., Haddar, A., Carmen GómezGuillén, M., Nasri, M., Montero, M.P., Bougatef, A.: Recovery, viscoelastic and functional properties of Barbel skin gelatine: investigation of anti-DPP-IV and anti-prolyl endopeptidase activities of generated gelatine polypeptides. Food Chem. 168, 478-486 (2015). https://doi.org/10.1016/j.foodchem.2014.07.086

96. Abdelmalek, B.E., Gómez-Estaca, J., Sila, A., Martinez-Alvarez, O., Gómez-Guillén, M.C., Chaabouni-Ellouz, S., Ayadi, M.A., Bougatef, A.: Characteristics and functional properties of gelatin extracted from squid (Loligo vulgaris) skin. LWT-Food Sci. Technol. 65, 924-931 (2016). https://doi.org/10.1016/j. lwt.2015.09.024

97. Zhang, Y., Dutilleul, P., Li, C., Simpson, B.K.: Alcalase-assisted production of fish skin gelatin rich in high molecular weight (HMW) polypeptide chains and their characterization for film forming capacity. LWT (2018). https://doi.org/10.1016/j. lwt.2018.12.012

98. Byler, D.M., Susi, H.: Examination of the secondary structure of proteins by deconvolved FTIR spectra. Biopolymers 25, 469-487 (1986). https://doi.org/10.1002/bip.360250307

99. Muyonga, J., Cole, C.G., Duodu, K.: Fourier transform infrared (FTIR) spectroscopic study of acid soluble collagen and gelatin from skins and bones of young and adult Nile perch (Lates niloticus). Food Chem. 86, 325-332 (2004). https://doi.org/10.1016/J. FOODCHEM.2003.09.038

100. Zhang, Q., Wang, Q., Lv, S., Lu, J., Jiang, S., Regenstein, J.M., Lin, L.: Comparison of collagen and gelatin extracted from the skins of Nile tilapia (Oreochromis niloticus) and channel catfish (Ictalurus punctatus). Food Biosci. 13, 41-48 (2016)

101. Qi, P., Zhou, Y., Wang, D., He, Z., Li, Z.: A new collagen solution with high concentration and collagen native structure perfectly preserved. RSC Adv. 5, 87180-87186 (2015). https://doi. org/10.1039/C5RA14423J

102. Júnior, Z.S.S., Botta, S.B., Ana, P.A., França, C.M., Fernandes, K.P.S., Mesquita-Ferrari, R.A., Deana, A., Bussadori, S.K.: Effect of papain-based gel on type I collagen-spectroscopy 
applied for microstructural analysis. Sci. Rep. 5, 11448 (2015). https://doi.org/10.1038/srep11448

103. Díaz-Calderón, P., Flores, E., González-Muñoz, A., Pepczynska, M., Quero, F., Enrione, J.: Influence of extraction variables on the structure and physical properties of salmon gelatin. Food Hydrocoll. 71, 118-128 (2017). https://doi.org/10.1016/J. FOODHYD.2017.05.004

104. Sun, L., Hou, H., Li, B., Zhang, Y.: Characterization of acid- and pepsin-soluble collagen extracted from the skin of Nile tilapia (Oreochromis niloticus). Int. J. Biol. Macromol. 99, 8-14 (2017). https://doi.org/10.1016/J.IJBIOMAC.2017.02.057

105. Feng, Y., Melacini, G., Taulane, J.P., Goodman, M.: Acetyl-terminated and template-assembled collagen-based polypeptides composed of Gly-Pro-Hyp sequences. 2. Synthesis and conformational analysis by circular dichroism, ultraviolet absorbance, and optical rotation. J. Am. Chem. Soc. 118, 10351-10358 (1996). https://doi.org/10.1021/ja961260c

106. Kozlowska, J., Sionkowska, A., Skopinska-Wisniewska, J., Piechowicz, K.: Northern pike (Esox lucius) collagen: extraction, characterization and potential application. Int. J. Biol. Macromol. 81, 220-227 (2015). https://doi.org/10.1016/j.ijbio mac.2015.08.002

107. Li, J., Wang, M., Qiao, Y., Tian, Y., Liu, J., Qin, S., Wu, W.: Extraction and characterization of type I collagen from skin of tilapia (Oreochromis niloticus) and its potential application in biomedical scaffold material for tissue engineering. Process Biochem. 74, 156-163 (2018). https://doi.org/10.1016/J.PROCB IO.2018.07.009

108. da Silva, E.V.C., Lourenço, L.D.F.H., Pena, R.S.: Optimization and characterization of gelatin from kumakuma (Brachyplatystoma filamentosum) skin. CyTA-J. Food. 15, 361-368 (2017). https://doi.org/10.1080/19476337.2016.1266391

109. Dorozhkin, V.S.: Bioceramics of calcium orthophosphates. Biomaterials 31, 1465-1485 (2010). https://doi.org/10.1016/j.bioma terials.2009.11.050

110. Boutinguiza, M., Pou, J., Comesaña, R., Lusquiños, F., De Carlos, A., León, B.: Biological hydroxyapatite obtained from fish bones. Mater. Sci. Eng., C 32, 478-486 (2012). https://doi. org/10.1016/j.msec.2011.11.021

111. Goto, T., Sasaki, K.: Effects of trace elements in fish bones on crystal characteristics of hydroxyapatite obtained by calcination. Ceram. Int. 40, 10777-10785 (2014). https://doi.org/10.1016/j. ceramint.2014.03.067

112. Huang, Y.C., Hsiao, P.C., Chai, H.J.: Hydroxyapatite extracted from fish scale: effects on MG63 osteoblast-like cells. Ceram. Int. 37, 1825-1831 (2011). https://doi.org/10.1016/j.ceram int.2011.01.018

113. Venkatesan, J., Kim, S.K.: Effect of temperature on isolation and characterization of hydroxyapatite from tuna (Thunnus obesus) bone. Materials 3, 4761-4772 (2010). https://doi.org/10.3390/ ma3104761

114. Piccirillo, C., Pullar, R.C., Tobaldi, D.M., Castro, L.P.M., Pintado, E.M.M.: Hydroxyapatite and chloroapatite derived from sardine by-products. Ceram. Int. 40, 13231-13240 (2014). https ://doi.org/10.1016/j.ceramint.2014.05.030

115. Prabakaran, K., Rajeswari, S.: Development of hydroxyapatite from natural fish bone through heat treatment. Trends Biomater. Artif. Organs 20, 20-23 (2006)

116. Sunil, B.R., Jagannatham, M.: Producing hydroxyapatite from fish bones by heat treatment. Mater. Lett. 185, 411-414 (2016). https://doi.org/10.1016/j.matlet.2016.09.039

117. Venkatesan, J., Qian, Z.J., Ryu, B., Thomas, N.V., Kim, S.K.: A comparative study of thermal calcination and an alkaline hydrolysis method in the isolation of hydroxyapatite from Thunnus obesus bone. Biomed. Mater. 6, 035003 (2011). https://doi. org/10.1088/1748-6041/6/3/035003
118. Mondal, S., Mahata, S., Kundu, S., Mondal, B.: Processing of natural resourced hydroxyapatite ceramics from fish scale. Adv. Appl. Ceram. 109, 234-239 (2010). https://doi. org/10.1179/174367613X13789812714425

119. Venkatesan, J., Lowe, B., Manivasagan, P., Kang, K.H., Chalisserry, E.P., Anil, S., Kim, D.G., Kim, S.K.: Isolation and characterization of nano-hydroxyapatite from salmon fish bone. Materials 8, 5426-5439 (2015). https://doi.org/10.3390/ma808 5253

120. Pon-On, W., Suntornsaratoon, P., Charoenphandhu, N., Thongbunchoo, J., Krishnamra, N., Tang, I.M.: Hydroxyapatite from fish scale for potential use as bone scaffold or regenerative material. Mater. Sci. Eng., C 62, 183-189 (2016). https://doi. org/10.1016/j.msec.2016.01.051

121. Muhammad, N., Gao, Y., Iqbal, F., Ahmad, P., Ge, R., Nishan, U., Rahim, A., Gonfa, G., Ullah, Z.: Extraction of biocompatible hydroxyapatite from fish scales using novel approach of ionic liquid pretreatment. Sep. Purif. Technol. 161, 129-135 (2016). https://doi.org/10.1016/j.seppur.2016.01.047

122. Kongsri, S., Janpradit, K., Buapa, K., Techawongstien, S., Chanthai, S.: Nanocrystalline hydroxyapatite from fish scale waste: preparation, characterization and application for selenium adsorption in aqueous solution. Chem. Eng. J. 215-216, 522-532 (2013). https://doi.org/10.1016/j.cej.2012.11.054

123. Mondal, S., Mondal, B., Dey, A., Mukhopadhyay, S.S.: Studies on processing and characterization of hydroxyapatite biomaterials from different bio wastes. J. Miner. Mater. Charact. Eng. 11, 55-67 (2012). https://doi.org/10.4236/jmmce.2012.111005

124. Panda, N.N., Pramanik, K., Sukla, L.B.: Extraction and characterization of biocompatible hydroxyapatite from fresh water fish scales for tissue engineering scaffold. Bioprocess Biosyst. Eng. 37, 433-440 (2014). https://doi.org/10.1007/s00449-013-1009-0

125. Haider, A., Haider, S., Han, S.S., Kang, I.K.: Recent advances in the synthesis, functionalization and biomedical applications of hydroxyapatite: a review. RSC Adv. 7, 7442-7458 (2017)

126. Adeoti, I.A., Hawboldt, K.: A review of lipid extraction from fish processing by-product for use as a biofuel. Biomass Bioenergy 63, 330-340 (2014). https://doi.org/10.1016/j.biomb ioe.2014.02.011

127. Rubio-Rodríguez, N., Beltrán, S., Jaime, I., de Diego, S.M., Sanz, M.T., Carballido, J.R.: Production of omega-3 polyunsaturated fatty acid concentrates: a review. Innov. Food Sci. Emerg. Technol. 11, 1-12 (2010). https://doi.org/10.1016/j.ifset.2009.10.006

128. Khoddami, A.: Quality and fatty acid profile of the oil extracted from fish waste (head, intestine and liver) (Euthynnus affinis). Afr. J. Biotechnol. (2012). https://doi.org/10.5897/ajb10.1699

129. Rodríguez, C., Acosta, C., Badía, P., Cejas, J.R., Santamaría, F.J., Lorenzo, A.: Assessment of lipid and essential fatty acids requirements of black seabream (Spondyliosoma cantharus) by comparison of lipid composition in muscle and liver of wild and captive adult fish. Comp. Biochem. Physiol. Part B Biochem. Mol. Biol. 139, 619-629 (2004)

130. Bonilla, J.R., Hoyos Concha, J.L.: Métodos de extracción, refinación y concentración de aceite de pescado como fuente de ácidos grasos omega-3. Cienc. y Tecnol. Agropecu. 19, 645-668 (2018). https://doi.org/10.21930/rcta.vol19_num2_art:684

131. Food and Agriculture Organization of the United Nations: The Production of Fish Meal and Oil. Food and Agriculture Organization of the United Nations, Rome (1986)

132. Thomas, A., Matthäus, B., Fiebig, H.: Ullmann's Encyclopedia of Industrial Chemistry, Vol. 14, pp. 1-70. Fats and fatty oils, Wiley-VCH Verlag GmbH \& Co. KGaA, Weinheim (2015)

133. Lee, J.Y., Yoo, C., Jun, S.Y., Ahn, C.Y., Oh, H.M.: Comparison of several methods for effective lipid extraction from microalgae. Bioresour. Technol. 101, S75-S77 (2010). https://doi. org/10.1016/j.biortech.2009.03.058 
134. Halim, R., Danquah, M.K., Webley, P.A.: Extraction of oil from microalgae for biodiesel production: a review. Biotechnol. Adv. 30, 709-732 (2012). https://doi.org/10.1016/j.biotechadv .2012.01.001

135. Mouahid, A., Crampon, C., Toudji, S.-A.A., Badens, E.: Supercritical $\mathrm{CO}_{2}$ extraction of neutral lipids from microalgae: experiments and modelling. J. Supercrit. Fluids 77, 7-16 (2013). https ://doi.org/10.1016/j.supflu.2013.01.024

136. Hathwar, S.C., Bijinu, B., Rai, A.K., Narayan, B.: Simultaneous recovery of lipids and proteins by enzymatic hydrolysis of fish industry waste using different commercial proteases. Appl. Biochem. Biotechnol. 164, 115-124 (2011). https://doi.org/10.1007/ s12010-010-9119-5

137. Qi-Yuan, L., Jun-Qing, Q., Xiao-Ge, W.: Optimization of enzymatic fish oil extraction from mackerel viscera by response surface methodology. Int. Food Res. J. 23, 992-997 (2016)

138. Fernández-Lorente, G., Betancor, L., Carrascosa, A.V., Guisán, J.M.: Release of omega-3 fatty acids by the hydrolysis of fish oil catalyzed by lipases immobilized on hydrophobic supports. JAOCS 88, 1173-1178 (2011). https://doi.org/10.1007/s1174 6-011-1776-1

139. Beheshti, S.: A study on the fatty acid composition of fish liver oil from two marine fish. Turk. J. Chem. 27, 251-258 (2003)

140. Christie, W.W., Han, X.: Lipid Analysis-Isolation, Separation, Identification and Lipidomic Analysis [Book Review]. Woodhead Publishing, Cambridge (2010)

141. Antolín, E.M., Delange, D.M., Canavaciolo, V.G.: Evaluation of five methods for derivatization and GC determination of a mixture of very long chain fatty acids (C24:0-C36:0). J. Pharm. Biomed. Anal. 46, 194-199 (2008). https://doi.org/10.1016/j. jpba.2007.09.015

142. Guil-Guerrero, J.L., Venegas-Venegas, E., Rincón-Cervera, M.Á., Suárez, M.D.: Fatty acid profiles of livers from selected marine fish species. J. Food Compos. Anal. 24, 217-222 (2011). https://doi.org/10.1016/j.jfca.2010.07.011

143. Van Wychen, S., Laurens, L.M.L.: Determination of total lipids as fatty acid methyl esters (FAME) by in situ transesterification. Contract 303, 275-3000 (2013)

144. Suganya, T., Kasirajan, R., Renganathan, S.: Ultrasoundenhanced rapid in situ transesterification of marine macroalgae Enteromorpha compressa for biodiesel production. Bioresour. Technol. 156, 283-290 (2014). https://doi.org/10.1016/j.biort ech.2014.01.050

145. Dodds, E.D., McCoy, M.R., Rea, L.D., Kennish, J.M.: Gas chromatographic quantification of fatty acid methyl esters: flame ionization detection vs. electron impact mass spectrometry. Lipids 40, 419-428 (2005). https://doi.org/10.1007/s11745-006-1399-8

146. Aursand, M., Gribbestad, I.S., Martinez, I.: Omega-3 fatty acid content of intact muscle of farmed Atlantic Salmon (Salmo salar) examined by $1 \mathrm{H}$ MAS NMR spectroscopy. Mod. Magn. Reson. 1, 941-945 (2008). https://doi.org/10.1007/978-3-319-28275 -6_80-1.pdf

147. Nilsang, S., Lertsiri, S., Suphantharika, M., Assavanig, A.: Optimization of enzymatic hydrolysis of fish soluble concentrate by commercial proteases. J. Food Eng. 70, 571-578 (2005). https:// doi.org/10.1016/j.jfoodeng.2004.10.011

148. Samaranayaka, A.G.P., Li-Chan, E.C.Y.: Autolysis-assisted production of fish protein hydrolysates with antioxidant properties from Pacific hake (Merluccius productus). Food Chem. 107, 768-776 (2008). https://doi.org/10.1016/j.foodchem.2007.08.076

149. Prabha, J., Narikimelli, A., Sajini, M.I., Vincent, S.: Optimization for autolysis assisted production of fish protein hydrolysate from underutilized fish Pellona ditchela. Int. J. Sci. Eng. Res. 4, 1863-1869 (2013)

150. dos Santos, S.D., Martins, V.G., Salas-Mellado, M., Prentice, C.: Evaluation of functional properties in protein hydrolysates from bluewing searobin (Prionotus punctatus) obtained with different microbial enzymes. Food Bioprocess Technol. 4, 1399-1406 (2011). https://doi.org/10.1007/s11947-009-0301-0

151. Galla, N.R., Karakala, B., Akula, S., Pamidighantam, P.R.: Physico-chemical, amino acid composition, functional and antioxidant properties of roe protein concentrates obtained from Channa striatus and Lates calcarifer. Food Chem. 132, 1171-1176 (2012). https://doi.org/10.1016/J.FOODCHEM.2011.11.055

152. Jemil, I., Abdelhedi, O., Mora, L., Nasri, R., Aristoy, M.-C., Jridi, M., Hajji, M., Toldrá, F., Nasri, M.: Peptidomic analysis of bioactive peptides in zebra blenny (Salaria basilisca) muscle protein hydrolysate exhibiting antimicrobial activity obtained by fermentation with Bacillus mojavensis A21. Process Biochem. 51, 2186-2197 (2016). https://doi.org/10.1016/J.PROCB IO.2016.08.021

153. Wald, M., Schwarz, K., Rehbein, H., Bußmann, B., Beermann, C.: Detection of antibacterial activity of an enzymatic hydrolysate generated by processing rainbow trout by-products with trout pepsin. Food Chem. 205, 221-228 (2016). https://doi. org/10.1016/J.FOODCHEM.2016.03.002

154. Egerton, S., Culloty, S., Whooley, J., Stanton, C., Ross, R.P.: Characterization of protein hydrolysates from blue whiting (Micromesistius poutassou) and their application in beverage fortification. Food Chem. 245, 698-706 (2018). https://doi. org/10.1016/J.FOODCHEM.2017.10.107

Publisher's Note Springer Nature remains neutral with regard to jurisdictional claims in published maps and institutional affiliations.

\section{Affiliations}

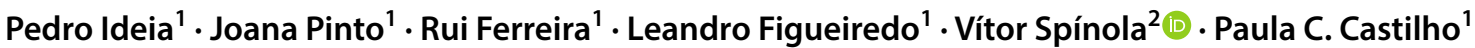

1 CQM - Centro de Química da Madeira, Universidade da Madeira, Campus da Penteada, 9020-105 Funchal, Madeira, Portugal
2 MadeBiotech - C R \& D, S. A., Zona Franca Industrial, Plataforma 28, Pavilhão Industrial K - Módulo 2, 9200-047 Caniçal, Madeira, Portugal 